\title{
A Novel Activator of CBP/p300 Acetyltransferases Promotes Neurogenesis and Extends Memory Duration in Adult Mice
}

\author{
Snehajyoti Chatterjee, ${ }^{1,3 *}$ Pushpak Mizar, ${ }^{1 *}$ Raphaelle Cassel, ${ }^{3 *}$ Romain Neidl, ${ }^{3}$ B. Ruthrotha Selvi, ${ }^{1}$ \\ Dalvoy Vasudevarao Mohankrishna, ${ }^{1}$ Bhusainahalli M. Vedamurthy, ${ }^{1}$ Anne Schneider, ${ }^{3}$ Olivier Bousiges, ${ }^{3}$ Chantal Mathis, ${ }^{3}$ \\ Jean-Christophe Cassel, ${ }^{3}$ Muthusamy Eswaramoorthy, ${ }^{2}$ Tapas K. Kundu, ${ }^{1}$ and Anne-Laurence Boutillier ${ }^{3}$ \\ ${ }^{1}$ Transcription and Disease Laboratory, Molecular Biology and Genetics Unit, and ${ }^{2}$ Chemistry and Physics of Materials Unit, Jawaharlal Nehru Centre for \\ Advanced Scientific Research, Jakkur, Bangalore 560064, India, and ${ }^{3}$ Laboratoire de Neurosciences Cognitives et Adaptatives, Unité Mixte de Recherche \\ 7364 Université de Strasbourg, Centre National de la Recherche Scientifique, Faculté de Psychologie, Groupe de Recherche 2905 NeuroMem, Strasbourg \\ 67000, France
}

\begin{abstract}
Although the brain functions of specific acetyltransferases such as the CREB-binding protein (CBP) and p300 have been well documented using mutant transgenic mice models, studies based on their direct pharmacological activation are still missing due to the lack of cell-permeable activators. Here we present a small-molecule (TTK21) activator of the histone acetyltransferases CBP/p300, which, when conjugated to glucosebased carbon nanosphere (CSP), passed the blood-brain barrier, induced no toxicity, and reached different parts of the brain. After intraperitoneal administration in mice, CSP-TTK21 significantly acetylated histones in the hippocampus and frontal cortex. Remarkably, CSP-TTK21 treatment promoted the formation of long and highly branched doublecortin-positive neurons in the subgranular zone of the dentate gyrus and reduced BrdU incorporation, suggesting that $\mathrm{CBP} / \mathrm{p} 300$ activation favors maturation and differentiation of adult neuronal progenitors. In addition, mRNA levels of the neuroD1 differentiation marker and BDNF, a neurotrophin required for the terminal differentiation of newly generated neurons, were both increased in the hippocampus concomitantly with an enrichment of acetylated-histone on their proximal promoter. Finally, we found that $\mathrm{CBP} / \mathrm{p} 300$ activation during a spatial training, while not improving retention of a recent memory, resulted in a significant extension of memory duration. This report is the first evidence for $\mathrm{CBP} / \mathrm{p} 300$-mediated histone acetylation in the brain by an activator molecule, which has beneficial implications for the brain functions of adult neurogenesis and long-term memory. We propose that direct stimulation of acetyltransferase function could be useful in terms of therapeutic options for brain diseases.
\end{abstract}

\section{Introduction}

Epigenetic modifications are emerging as fundamental mechanisms involved in regulations of adaptive behaviors (Hsieh and

Received Dec. 18, 2012; revised April 18, 2013; accepted May 8, 2013.

Author contributions: S.C., P.M., R.C., B.R.S., T.K.K., and A.-L.B. designed research; S.C., P.M., R.C., R.N., B.R.S., D.V.M., B.M.V., A.S., O.B., M.E., T.K.K., and A.-L.B. performed research; S.C., P.M., R.C., R.N., B.R.S., D.V.M., B.M.V., A.S., O.B., C.M., J.-C.C., M.E., T.K.K., and A.-L.B. analyzed data; S.C., J.-C.C., T.K.K., and A.-L.B. wrote the paper.

This work was supported by the Centre National de la Recherche Scientifique, the University of Strasbourg, the Department of Biotechnology, the Government of India (Grant \#BT/ CSH/GIA/1752 to T.K.K.), the Jawaharlal Nehru Centre for Advanced Scientific Research, ANR (Grant \#ANR-12-MALZ-0002-01 to A.-L.B.), the Indo-French Centre for the Promotion of Advanced Research (Grant \#4803-3 to T.K.K. and A.-L.B.), Ligue Européenne Contre la Maladie d'Alzheimer (Project \#10702 to A.-L.B.), and Alsace Alzheimer 67 (to A.-L.B. and Dr. F. Blanc). T.K.K. is the recipient of a Sir J.C. Bose national fellowship, Department of Science and Technology, Government of India. R.C. and R.N. are recipients of a doctoral fellowship from the French government. A.S. is supported by the Fondation Unistra-don Pierre Fabre and by the ANR (Grant \#ANR-12-MALZ-0002-01). We thank 0. Bildstein, 0. Egesi, and G. Edomwonyi (Unité Mixte de Recherche 7364) for assistance in animal care and B. Cosquer, K. Herbeaux, and M.-M. Klein (Unité Mixte de Recherche 7364) for excellent technical assistance. We thank Parijat Senapati and Dr Rahul Modak for providing the p300 enzyme. Publication costs are supported by the Neurex network.

The authors declare no competing financial interests.

*S.C., P.M., and R.C. contributed equally to this work.

Correspondence should be addressed to either of the following: Anne-Laurence Boutillier, Laboratoire de Neuroscience Cognitive et Adaptative, UMR 7364 CNRS, Université de Strasbourg, 12 rue Goethe, 67000 Strasbourg, France, E-mail: laurette@unistra.fr; or Tapas K. Kundu, Transcription and Disease Laboratory, Molecular Biology and Genetics Unit, Jawaharlal Nehru Centre for Advanced Scientific Research, Jakkur, Bangalore 560064, India, E-mail: tapas@jncasr.ac.in.

DOI:10.1523/JNEUROSCI.5772-12.2013

Copyright $\odot 2013$ the authors $\quad 0270-6474 / 13 / 3310698-15 \$ 15.00 / 0$
Eisch, 2010; Gräff et al., 2011). The site-specific acetylation of histone proteins within chromatin is an epigenetic modification that participates in the regulation of gene expression and, although highly dynamic, is believed to produce long-lasting changes that sustain physiological processes and behavior (Gräff et al., 2011). In neurons particularly, where de novo gene expression is known to support long-term memory formation, histone acetylation greatly participates in synaptic plasticity, learning, and memory (for review, see Peixoto and Abel, 2013). Epigenetic alterations, including those on histone acetylation, can lead to the cognitive dysfunctions found in pathological conditions (Gräff et al., 2012). Therefore, pharmacological enhancement of signaling, including transcriptional processes that mediate long-term memory formation, provides a potential therapeutic strategy for cognitive disorders involving aberrant neuroplasticity.

Reversible acetylation is regulated by specific enzymes, histone/lysine acetyltransferases (HAT/KAT), which add an acetyl group to lysine residues of proteins including histone tails and deacetylases (HDACs) catalyzing the opposite reaction (Yang and Seto, 2007). During the last decade, investigators have modulated cellular acetylation homeostasis in neurodegenerative conditions, especially those associated with cognitive impairments, using HDAC inhibitors as a potential therapeutic intervention (Kazantsev and Thompson, 2008; Fischer et al., 2010). However, caveats remain as to the specificity of these inhibitors, 
A<smiles>O=C(O)C1CCCCC1C(=O)O</smiles>

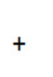

A
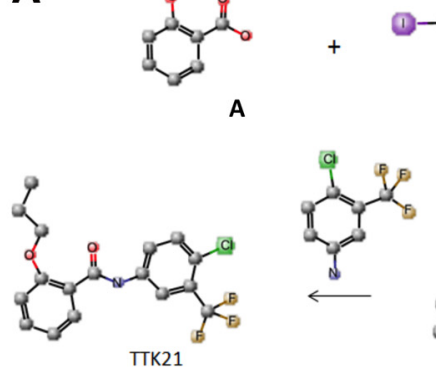

B

$\begin{array}{rccccccc}\text { Core histones } & + & + & + & + & + & + & + \\ \text { Recomb. HAT } & + & + & + & + & + & + & + \\ \text { [HH] Acetyl-coA } & - & + & + & + & + & + & + \\ \text { DMSO } & - & - & + & + & + & + & + \\ \text { TTK21 }(\mu M) & - & - & - & 50 & 100 & 200 & 275\end{array}$
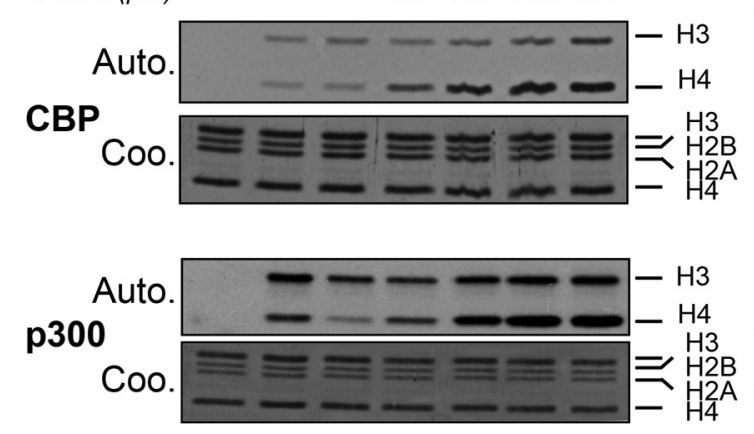

E
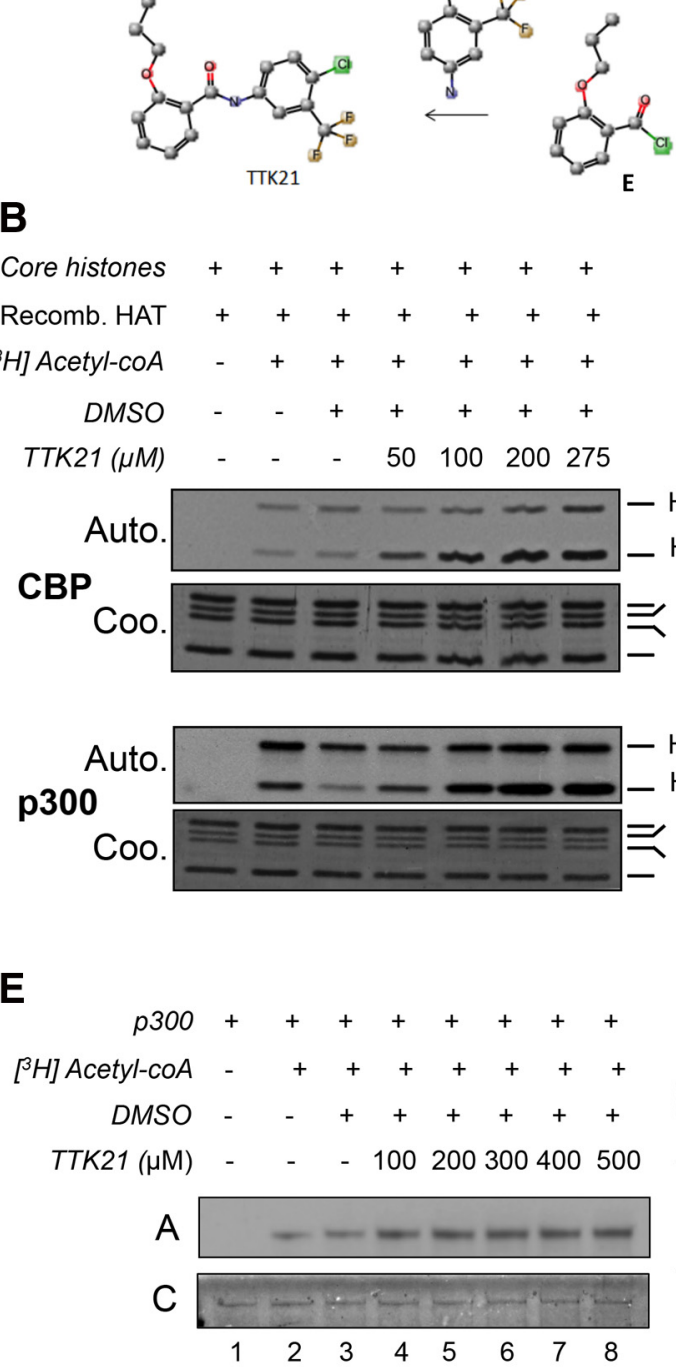

$\mathbf{E}$ $\underset{\text { Acetone }}{\stackrel{\mathrm{K}_{2} \mathrm{CO}_{3}}{\longrightarrow}}$
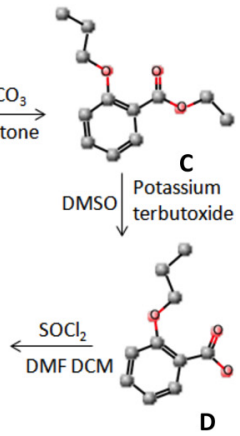

C
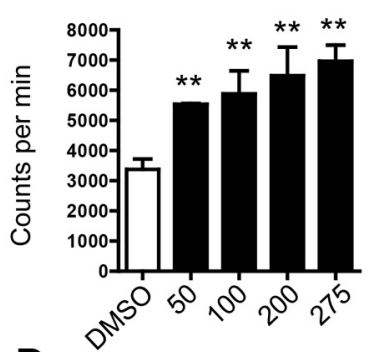

D
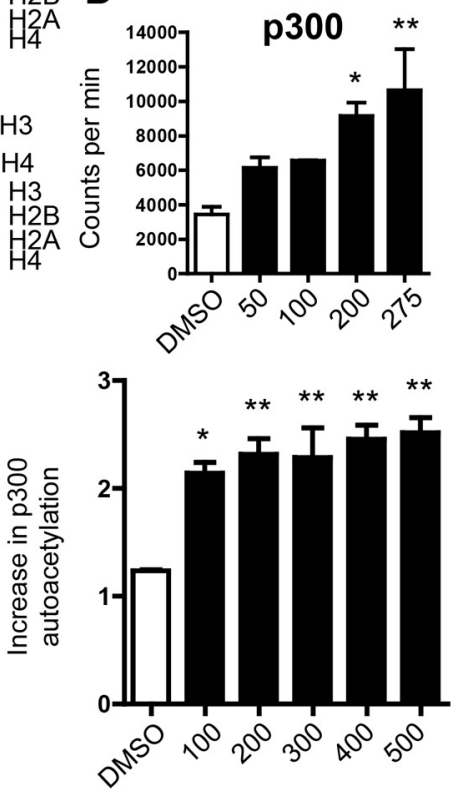

Figure 1. Small-molecule activator of lysine acetyltransferase (KAT) CBP/ p300. A, Synthesis of the KAT activator TTK21 from salicylic acid. $\boldsymbol{B}$, Gel fluorography assay shows a concentration-dependent activation of CBP and p300 by TTK21. TTK21 at different concentrations $(50,100,200$, and $275 \mu \mathrm{m}$ as noted) dissolved in DMSO was added to reaction mixture to the desired concentration. Auto indicates autoradiogram; Coo, Coomassie gel. C, $\boldsymbol{D}$, Concentration-dependent activation of CBP ( $\boldsymbol{C}$ ) and p300 (D) by TTK21 as shown by filter-binding assay using TTK21 at 50, 100, 200, and $275 \mu \mathrm{m}$. One-way ANOVA followed by Dunnett's test comparing all columns to DMSO control column $\left({ }^{* *} p<0.01 ;{ }^{*} p<0.05, n=4\right)$. $E$, Effect of TTK21 on the $\mathrm{p} 300$ auto-acetylation activity. Left: Autoradiogram showing auto-acetylation assays performed using full-length $\mathrm{p} 300$ in the absence of radioactive acetyl $\mathrm{COA}\left[{ }^{3} \mathrm{H}\right]$ (lane 1 ) and in the presence of radioactive acetyl $\mathrm{COA}\left[{ }^{3} \mathrm{H}\right]$ (lanes 2-8); lanes 4-8, $\mathrm{p3} 00$ in the presence of increasing concentrations of TTK21 (100-500 $\mu \mathrm{M})$; lane 3, DMS0 only added as solvent control. Reaction mixtures were resolved by SDS-PAGE and processed for fluorography. Right: Quantification of the intensities of the bands from the autoradiogram. One-way ANOVA followed by Dunnett's test comparing all columns with the DMSO control column $\left({ }^{* *} p<0.01 ;{ }^{*} p<0.05, n=3\right)$.

and their long-term effects could be detrimental to the neurons. Therefore, the direct pharmacological activation of acetyltransferases could be an alternative that was not developed due to the lack of a cell-permeable HAT/KAT activator. The role of specific acetyltransferases such as the CREB-binding protein (CBP) in learning and memory has been demonstrated quite convincingly by knock-down and deletion studies (Barrett and Wood, 2008; CBP

Chen et al., 2010; Barrett et al., 2011; Valor et al., 2011). The continued requirement of specific acetyltransferases throughout life may be required in addition to their proper developmental regulation (Barco, 2007). Our recent data demonstrated that the expression of several acetyltransferases (including $\mathrm{CBP} / \mathrm{p} 300$ ) increased in the course of spatial memory acquisition, bringing the importance of their dynamic regulation during memory formation into question (Bousiges et al., 2010). Recently, a successful rescue of learning and memory defects was achieved by viral brain delivery of CBP into the hippocampus of a mouse model of Alzheimer's disease (Caccamo et al., 2010). These studies support the development of molecules able to stimulate the acetyltransferase function directly as a new potential therapeutic tool for treating memory dysfunctions, including Alzheimer's disease (Selvi et al., 2010; Valor et al., 2013).

The present study provides the first evidence for pharmacological HAT/ KAT activation (CBP/p300) after systemic injection of a carbon-nanosphere-coupled small activator molecule (CSP-TTK21) in adult mice. This activation has direct consequences on brain functions because it induced differentiation of newly generated neurons and extended memory duration. Therefore, by promoting increased plasticity, acetyltransferase activators such as CSPTTK21 could have a significant impact on detrimental age-related brain decline.

\section{Materials and Methods}

Synthesis of TTK21

For synthesis of TTK21 (Fig. 1), salicylic acid A (14.5 mmol) and iodopropane B (43.4 mmol) dissolved in acetone were added to anhydrous $\mathrm{K}_{2} \mathrm{CO}_{3}(43.4 \mathrm{mmol})$. The reaction mixture was refluxed for 3-4 h and, upon completion, evaporated in a vacuum and treated using ethyl acetate and water. The combined organic extract was dried over $\mathrm{NaSO}_{4}$ and then evaporated. The crude product thus obtained was purified using ethyl acetate and hexane (1:20) as an eluent to yield $94 \%$ of the pure product C. Potassium tertiary butoxide (11 $\mathrm{mmol})$ was added to solution of $\mathrm{C}(9 \mathrm{mmol})$ in DMSO at $0^{\circ} \mathrm{C}$. The reaction mixture was stirred at $0^{\circ} \mathrm{C}$ for $30 \mathrm{~min}$ and then at room temperature for 2-3 h. The reaction upon completion was treated using ice-cold water and then extracted with dichloromethane (DCM). The combined organic layer was dried over $\mathrm{NaSO}_{4}$ and then evaporated. The crude product thus obtained was purified by recrystallization using ethanol as the solvent to obtain $95 \%$ of the desired product D. Solution D $(3.3 \mathrm{mmol})$ in $10 \mathrm{ml}$ of DCM was cooled in ice and a cold solution of $\mathrm{SOCl}_{2}(3.66 \mathrm{mmol})$ dissolved in $2 \mathrm{ml}$ of DCM was added dropwise. A few drops of dimethyl formamide (DMF) were added to the solution. The reaction mixture was refluxed for $2 \mathrm{~h}$. Upon completion, the reaction was evaporated in vacuum to obtain crude product E. Compound D was dissolved in DCM $(3.1 \mathrm{mmol})$ in 
another round-bottom flask and a solution of $\mathrm{Et}_{3} \mathrm{~N}(5.58 \mathrm{mmol})$ was added dropwise at $0^{\circ} \mathrm{C}$. The reaction mixture was stirred at room temperature for $30 \mathrm{~min}$. The resulting solution was added dropwise to the crude product $\mathrm{E}$ dissolved in DCM. The reaction mixture was refluxed for 3-4 $\mathrm{h}$. The reaction upon completion was treated using water and DCM. The combined organic extract was evaporated in a vacuum to yield a crude product that was purified using recrystallization to yield the pure product TTK21 (92\% yield).

\section{Conjugation of CSP with TTK21}

The carbon nanospheres (CSP) were prepared by the hydrothermal treatment of glucose at $180^{\circ} \mathrm{C}$ for $18 \mathrm{~h}$ (Selvi et al., 2008). One equivalent of $\mathrm{SOCl}_{2}$ diluted in DCM was added dropwise to a suspension of $100 \mathrm{mg}$ of CSP in DCM, followed by the addition of few drops of DMF (Fig. 2B). The reaction mixture was stirred at room temperature for $8-9 \mathrm{~h}$. TTK21 dissolved in DCM was added dropwise to this solution. The reaction mixture was stirred for $8-9 \mathrm{~h}$ at room temperature. The solvent was then evaporated and washed with cold water. The crude product was centrifuged and the supernatant (i.e., water) was removed; this procedure was repeated 7-8 times. Washing was then performed using DCM and the supernatant was subsequently tested for absence of TTK21. The CSP-TTK2 1 conjugated was then dried at $60^{\circ} \mathrm{C}$ for $2-3 \mathrm{~d}$.

\section{Core histone purification from $\mathrm{HeLa}$ nuclear pellet}

The HeLa nuclear pellet was homogenized in $0.1 \mathrm{M}$ potassium phosphate buffer, $\mathrm{pH}$ 6.7, containing $0.1 \mathrm{~mm}$ EDTA, $10 \%$ glycerol, $0.1 \mathrm{~mm}$ PMSF, and $0.1 \mathrm{~mm}$ DTT with a $630 \mathrm{~mm}$ salt concentration. The supernatant was kept for binding with hydroxyapatite. Subsequent washes were with $630 \mathrm{~mm}$ salt over a prolonged period (12 h). Histone octamer was eluted with $2 \mathrm{M}$ salt and dialyzed against BC100 (20 mM Tris, pH 7.9, $100 \mathrm{~mm} \mathrm{KCl,} \mathrm{20 \%} \mathrm{glycerol,} 0.1 \mathrm{~mm}$ DTT). The Bio-Rad protein reagent assay was used to estimate the protein concentration and electrophoresed on $15 \%$ SDS PAGE.

\section{Purification of recombinant proteins}

Full-length $\mathrm{His}_{6}$-p300 was purified from recombinant baculovirus-infected Sf 21 cells as described previously (Kundu et al., 1999). Briefly, Sf cells were infected with appropriate concentration of recombinant baculovirus followed by affinity chromatography of the cell lysate using Ni-NTA resin (Qiagen). FLAG-tagged CBP was also purified using similar techniques of infection of recombinant baculovirus into Sf 21 cells, followed by affinity chromatography of the cell lysate using M2agarose beads (Sigma). The proteins were eluted using FLAG peptide (Sigma).

\section{HAT assays}

Filter-binding assays. Highly purified HeLa core histones were incubated in HAT assay buffer at $30^{\circ} \mathrm{C}$ for $10 \mathrm{~min}$ with or without baculovirusexpressed recombinant p300 or CBP in the presence or absence of TTK21, followed by addition of $1 \mu \mathrm{l}$ of $3.6 \mathrm{Ci} / \mathrm{mmol}\left[{ }^{3} \mathrm{H}\right]$ acetyl-CoA (NEN-PerkinElmer) and incubated for $10 \mathrm{~min}$ in a final volume of $30 \mu \mathrm{l}$ at $30^{\circ} \mathrm{C}$. The mixture was blotted onto P-81 (Whatman) filter paper and antibodies against acetyl H3Lys 14.
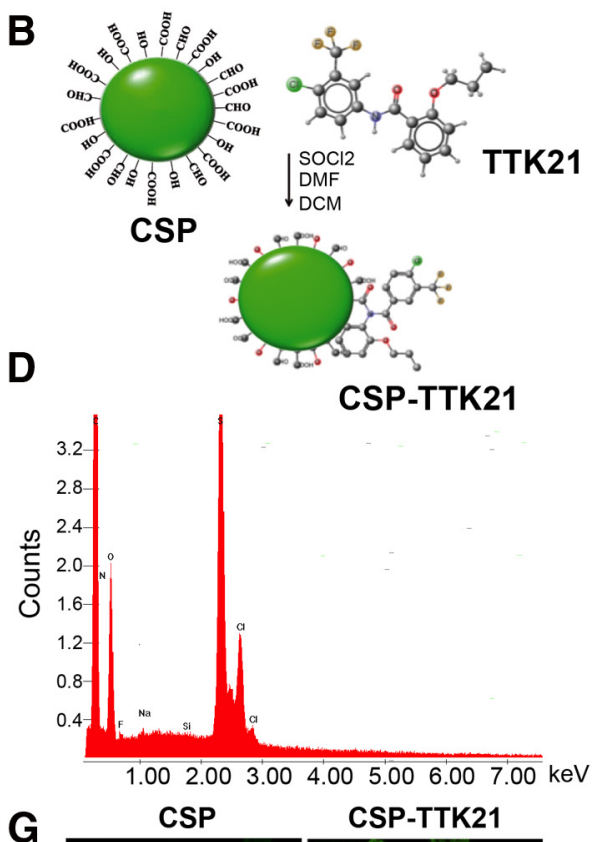

G

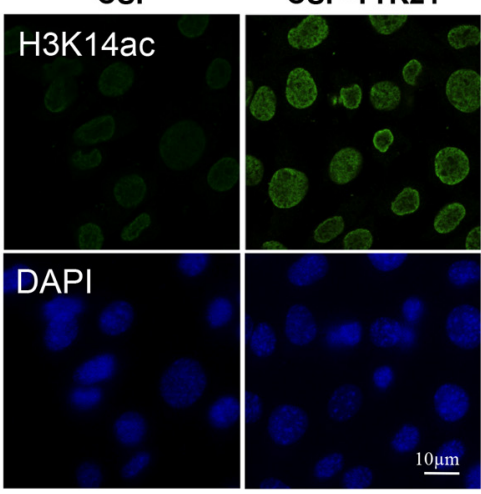

Figure 2. CSP conjugated activator (TTK21) induces histone H3 acetylation in SHSY-5Y neural cells. A, TTK21 alone is impermeable to cells. Western blot analysis of TTK21 untreated and treated HeLa cells for $24 \mathrm{~h}$. Lane 1, untreated cells; lane 2, DMS0-treated spectrum histone deacetylase inhibitor NaBu-treated cells showing hyperacetylation of histone $\mathrm{H} 3$. Acetylated $\mathrm{H} 3$ antibody was 作

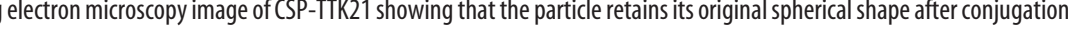
$\mu \mathrm{g} / \mathrm{ml}$ ) treated for 6 and $12 \mathrm{~h}$ (lanes 2 and 3, respectively) and CSP-TTK21 (50 $\mu \mathrm{g} / \mathrm{ml})$ upon 6, 12, and $24 \mathrm{~h}$ of treatment (lanes 4 , 5 , and 6, respectively) using antibodies against acetyl H3Lys 14 and reprobed with $\mathrm{H} 3$ antibody. G, SHSY-5Y cells were treated with CSP-TTK21 $(50 \mu \mathrm{g} / \mathrm{ml})$, CSP (50 $\mu \mathrm{g} / \mathrm{ml})$ for $24 \mathrm{~h}$ and histone acetylation was estimated by immunofluorescence analysis using

radioactive counts were recorded on a Wallac 1409 liquid scintillator counter.

Gel fluorography assay. Histones were isolated by TCA precipitation using 25\% TCA. The pellet was washed twice with acetone and dissolved in $2 \times$ SDS loading dye, heated for $5 \mathrm{~min}$, and separated using $15 \%$ SDS-PAGE. Coomassie staining was performed to ascertain the presence of equal loading in each reaction and was later dehydrated in DMSO for $1 \mathrm{~h}$. Dehydrated gel was later incubated in scintillation fluid (2,5 diphenyl oxazole solution in DMSO) for $45 \mathrm{~min}$ and rehydrated again in distilled water for $4 \mathrm{~h}$. The gel was then dried using a gel drier and later exposed in an $\mathrm{x}$-ray cassette using a film for $5 \mathrm{~d}$ in a $-80^{\circ} \mathrm{C}$ cooler. The film was then developed to obtain the intensity profiles for each of the reactions.

p300 Auto-acetylation assay. Auto-acetylation reactions of full-length p300 were performed in lysine acetyltransferase assay buffer at $30^{\circ} \mathrm{C}$ for 10 min with or without TTK21, followed by the addition of $1 \mu \mathrm{l}$ of 4.7 
$\mathrm{Ci} / \mathrm{mmol}\left[{ }^{3} \mathrm{H}\right]$ acetyl-CoA (NEN-PerkinElmer). The reaction mixture was further incubated for another $10 \mathrm{~min}$ at $30^{\circ} \mathrm{C}$. The ${ }^{3} \mathrm{H}$-labeled acetylated p300 was visualized by fluorography followed by autoradiography.

Immunofluorescence in SHSY-5Y cells. Cells were grown on poly-Llysine-coated coverslips at $37^{\circ} \mathrm{C}$ in a $5 \% \mathrm{CO}_{2}$ incubator. After treatment for the indicated times, cells were washed with PBS and fixed with $4 \%$ paraformaldehyde (in PBS) for $20 \mathrm{~min}$ at room temperature. Cells were permeabilized using $1 \%$ Triton X-100 (in PBS) for $10 \mathrm{~min}$ and washed with PBS for $3 \times 10 \mathrm{~min}$. Nonspecific blocking was performed using $5 \%$ FBS (in PBS) for $45 \mathrm{~min}$ at $37^{\circ} \mathrm{C}$. Primary antibody was added in appropriate dilutions for $1 \mathrm{~h}$ at room temperature. Cells were then washed with washing buffer (1\% FBS in PBS) 4 times at 3 min each. Secondary antibody tagged with fluorescent dye was added in appropriate dilutions for $1 \mathrm{~h}$ at room temperature, followed by washes with washing buffer. The nuclei were then stained with Hoechst (1:10,000 dilutions) for $20 \mathrm{~min}$. After two PBS washes, coverslips were inverted onto a microscopic slide with $>2 \mu \mathrm{l}$ of $70 \%$ glycerol (in PBS) and imaged using a confocal microscope.

Animals. Experimental protocols and animal care were in compliance with the institutional guidelines (council directive 87/848, October 19, 1987, Ministère de l'agriculture et de la Forêt, Service Vétérinaire de la Santé et de la Protection Animale) and international laws (directive 86609, 24 November 1986, European Community) and policies (personal authorizations \#67-117 for A.-L.B., \#67-215 for J.-C.C., and \#67-292 for C.M.). B57BL6/6J male mice were purchased from Charles River Laboratories and behaviorally tested at $\sim 3$ months of age. They were housed individually under a $12 \mathrm{~h}$ light/dark cycle (lights on at 7:00 A.M.). Access to food and water was ad libitum in a temperature- and humiditycontrolled room $\left(22 \pm 1^{\circ} \mathrm{C}\right.$ and $55 \pm 5 \%$, respectively).

Immunofluorescence and Immunohistochemistry for animal tissue. Mice were injected with indicated amounts of the molecules. For BrdU counting, mice were injected with $100 \mathrm{mg} / \mathrm{kg} \mathrm{BrdU}$ (B5002; Sigma) according to different protocols as noted in the text and represented in Figure $5 G$, $H, J$. After defined time periods, mice were deeply anesthetized with pentobarbital $(60 \mathrm{mg} / \mathrm{kg})$ and perfused transcardially with $150 \mathrm{ml}$ of ice-cold paraformaldehyde ( $4 \%$ in $0.1 \mathrm{M} \mathrm{PB}, 4^{\circ} \mathrm{C}$ ). Brains were then rapidly removed from the skull and postfixed for $6 \mathrm{~h}$ in the same fixative at $4^{\circ} \mathrm{C}$. Fixed brains were then kept in sucrose at $4^{\circ} \mathrm{C}$ for $48 \mathrm{~h}$. Freezing of the brains was performed in isopentane for $1 \mathrm{~min}$ at $-40^{\circ} \mathrm{C}$. The brains were stored in $\mathrm{a}-80^{\circ} \mathrm{C}$ freezer until being further processed. Coronal sections, $20 \mu \mathrm{m}$ in thickness, were made through the dorsal hippocampus using a Vibratome (VT1000M; Leica). The tissue sections were permeabilized in $1 \times \mathrm{PBS} /$ Triton X-100 2\% for $15 \mathrm{~min}$. Nonspecific labeling was blocked by $1 \times \mathrm{PBS} / 0.1 \%$ Triton X-100/5\% horse serum for $30 \mathrm{~min}$ at $37^{\circ} \mathrm{C}$. For BrdU immunolabeling, sections were denatured for $2 \mathrm{~h}$ in 2 $\mathrm{N} \mathrm{HCl}$ at room temperature and then washed 4 times in PBS, $\mathrm{pH} 7.35$, prior to the blocking step. The sections were then incubated overnight with the indicated antibodies (doublecortin [DCX] \#sc-8066, Santa Cruz Biotechnology; acetylated-H3K14 \#1921, Epitomics; acetyl-histone H2B \#07-373, Millipore). After 3 washes, sections were incubated with the appropriate secondary antibody. For immunofluorescence, sections were incubated with donkey anti-rabbit conjugated with fluorescent dye ( $1 \mathrm{~h}$ at room temperature), followed by 3 washes with $1 \times \mathrm{PBS} / 0.1 \%$ Triton X-100, and the nuclei were stained with Hoechst (1:1000 dilutions) for $5 \mathrm{~min}$. After two PBS washes, the sections were mounted. For immunohistochemistry, sections were further incubated with anti-rabbit horseradish peroxidase-conjugated antibody (\#sc2004; Santa Cruz Biotechnology) for $1 \mathrm{~h}$. After three washes with $1 \times \mathrm{PBS} / 0.1 \%$ Triton X-100, $0.05 \% \mathrm{DAB}$ (with $0.04 \mathrm{~m}$ Tris, $\mathrm{pH} 7.5,0.03 \% \mathrm{H}_{2} \mathrm{O}_{2}$ ) was added and sections were mounted with a Roti Histokit II (Roth). For immunofluorescence, images were acquired with a Zeiss LSM510 confocal imaging system.

DCX-positive neurons, dendritic length, and branching counting. Counting was done in two groups of mice (CSP or CSP-TTK21, $n=$ 3 /group) that were left in their home cages for $3 \mathrm{~d}$ after injections. After DCX immunohistochemistry, images were acquired with a Zeiss LSM510 confocal imaging system and analyzed with the Zeiss LSM image browser. Sections containing the dorsal hippocampus ( $n=4-6 /$ animal $)$ were then evaluated by an experimenter blind to the treatment for the number of DCX-positive neurons. For each of these sections, the longest dendrite of each DCX-positive neuron was drawn on the image and the lengths given by the software were averaged per animal. One area in a similar hippocampal region was cropped out $(n=5$ /animal $)$ and lines were drawn at 60, 90, and $120 \mu \mathrm{m}$ from the DCX-positive nuclei (in the subgranular zone [SGZ]). The number of dendrites crossing each of these lines was then counted and averaged per hippocampus per animal.

Protein preparation and Western blot analyses. Animals were killed by cervical elongation. Their brains were rapidly removed from the skull and transferred on ice. Freshly dissected tissues were then immediately frozen at $-80^{\circ} \mathrm{C}$. Tissues were lysed and homogenized in Laemmli buffer. After $10 \mathrm{~min}$ at $70^{\circ} \mathrm{C}$, samples were sonicated for $10 \mathrm{~s}$ (ultrasonic processor, power $60 \%)$, boiled $5 \mathrm{~min}$, centrifuged $(20,000 \times g$ for $5 \mathrm{~min})$ and the supernatant was frozen at $-20^{\circ} \mathrm{C}$. Protein concentration was measured using the RC-DC Protein Assay (Bio-Rad). Western blots were performed as described previously (Bousiges et al., 2010) with antibodies against acetyl-histone H2B (\#07-373; Millipore), acetylated-histone H2BK5 (\#07-382; Millipore), H3 histone (\#ab1791; Abcam), acetyl histone H3 lys 14 (\#1921; Epitomics), acetyl Histone H3 (\#06-599; Millipore), and H2B histone (\#H2-28; Euromedex); pro-BDNF (\#AB9612; Millipore), GFAP (\#MAB360; Millipore), NeuN (\#ABN78; Millipore), and $\beta$-actin (\#ab16039; Abcam). Secondary HRP-conjugated antibodies were from Jackson ImmunoResearch. Blots were revealed with ECL and exposed with Hyperfilm ECL (GE Healthcare). Results were quantified using ImageJ software.

Real-time $q R T$-PCR. Tissues were finely cut with a razor blade and homogenized with a Dounce in TRIzol reagent (Invitrogen). After chloroform extraction, RNAs were ethanol precipitated twice. Only RNA samples with an OD 260/280 and OD 260/230 ratio close to 2.0 were selected for reverse transcription. RNA samples were denaturated $10 \mathrm{~min}$ at $70^{\circ} \mathrm{C}$ and cDNA synthesis was performed on $1 \mu \mathrm{g}$ of total RNA (iScript cDNA synthesis kit; Bio-Rad). qRT-PCR analysis was performed on a Bio-Rad iCycler System (CFX) using SsoAdvanced SYBR Green SuperMix (Bio-Rad). A specific standard curve was performed in parallel for each gene, and each sample was quantified in duplicate $(n=5-6)$. qRTPCR conditions were $3 \mathrm{~min}$ at $94^{\circ} \mathrm{C}$, followed by 40 cycles of $45 \mathrm{~s}$ at $94^{\circ} \mathrm{C}$ and $10 \mathrm{~s}$ at $60^{\circ} \mathrm{C}$. Data were analyzed by gene regression using iCycler software and normalized to the polymerase II RNA levels.

Chromatin immunoprecipitation. Freshly dissected tissues were chopped with a razor blade and rapidly put in $5 \mathrm{ml}$ of PBS containing $1 \%$ formaldehyde for $15 \mathrm{~min}$ at room temperature. The fixation step was stopped by the addition of glycine ( $0.125 \mathrm{M}$ final concentration). Samples were prepared as described previously (Panteleeva et al., 2007), snap frozen in liquid nitrogen, and stored at $-80^{\circ} \mathrm{C}$ until needed. An equal amount $(120 \mu \mathrm{g})$ of DNA/protein complex was assayed and brought to a volume of $500 \mu \mathrm{l}$ of with chromatin immunoprecipitation dilution buffer $(0.01 \%$ SDS, $1.1 \%$ Triton X-100, 1.2 mm EDTA, 16.7 mm Tris-Cl, pH $8.1,167 \mathrm{~mm} \mathrm{NaCl})$. A fraction of supernatants $(20 \mu \mathrm{l})$ from each sample were saved before immunoprecipitation and served as "total input chromatin." The remaining supernatant was incubated overnight at $4^{\circ} \mathrm{C}$ with $2 \mu \mathrm{g}$ of the primary antibody against acetyl-histone H2B (\#ab1759; Abcam) or no antibody (negative control). This was followed by incubation with a mix of protein A/G Dynabeads (Invitrogen) for $2 \mathrm{~h}$. After several wash steps (low salt, high salt, $\mathrm{LiCl}$, and TE buffers), complexes were eluted in $200 \mu \mathrm{l}$ of elution buffer ( $\left.1 \% \mathrm{SDS}, 0.1 \mathrm{M} \mathrm{NaHCO}_{3}\right)$. The crosslinking was reversed (overnight at $65^{\circ} \mathrm{C}$ ) and the DNA was subsequently purified with RNase $\left(30 \mathrm{~min}\right.$ at $\left.37^{\circ} \mathrm{C}\right)$, proteinase $\mathrm{K}\left(2 \mathrm{~h}\right.$ at $\left.45^{\circ} \mathrm{C}\right)$, phenol/ chloroform extraction, and ethanol precipitation. After a last wash with $70 \%$ ethanol, pellets were resuspended in $50 \mu \mathrm{l}$ of nuclease-free Milli-Q water and analyzed by semiquantitative PCR (MyCycler system; BioRad). Primers for neuroD1 promoter were as follows: left: $5^{\prime}$ gtccgcggagtctctaactg- $3^{\prime}$ and right: $5^{\prime}$-gaaccacgtgacctgcctat- $3^{\prime}$, and those for bdnf PI and IV have been described previously (Zajac et al., 2010). Chromatin immunoprecipitations were quality controlled by the use of control genes that were either expressed ubiquitously (GAPDH) or not expressed in the hippocampus (TSH2B).

Statistical analysis of biochemical studies. Statistical analyses were performed using Student's $t$ test or one-way ANOVA followed by NeumanKeuls multiple-comparison test when appropriate (Prism software 
version 4.0b; GraphPad). Data are expressed as the means \pm SEM. Differences at $p<0.05$ were considered significant.

Spatial learning and memory testing in the Morris water maze. Using a circular pool $(\varnothing 140)$ half-filled with opaque water $\left(22^{\circ} \mathrm{C}\right)$ and located in a room with several well contrasted extra-maze cues, the aversively motivated task consisted of the mice learning, over four successive trials/d, the location of an escape platform hidden under the water surface at a fixed position. The two first training days were for habituation to increasing water levels. The strength and precision of memory were tested in a probe trial, for which the platform was removed and the animal was left for $60 \mathrm{sin}$ the water. When remembering the platform location, the mice typically displayed a swimming pattern focused on the quadrant of the former platform location (where they typically spent a cumulated time corresponding to $35-50 \%$ of the probe trial duration). Ten to 12 mice in each group (CSP or CSP-TTK21 injected) were trained for task acquisition over three consecutive days ("weak learning"). The distance was recorded by a video tracking system (Ethovision; Noldus). The variable taken into account for probe trial analysis was the time spent in each of the four quadrants.

Statistical analyses for behavioral studies. Performance recorded during acquisition (latency to the platform) was evaluated using a two-way ANOVA for repeated measures considering the factors of "day" (1-3) and "treatment" (CSP vs CSP-TTK21). Probe trial performance was analyzed using a $t$ test comparing the time spent in the target quadrant to chance (i.e., $15 \mathrm{~s}$ ) and the time spent in the target quadrant to the average time in the other three quadrants. Values of $p<0.05$ were considered significant and are noted in the text.

\section{Results}

TTK21, a small-molecule activator of CBP/p300 acetyltransferases induces acetylation in vitro

Based on the previously discovered first small-molecule HAT/ KAT activator CTPB (Balasubramanyam et al., 2003), we have synthesized several derivatives. Through a low-throughput enzyme assay screening, TTK21 ( $N$-(4-chloro-3-trifluoromethylphenyl)-2-N-propoxy-benzamide) was selected. The synthesis steps of TTK21 are depicted in Figure $1 A$ (see Materials and Methods) where salicylic acid was taken as a synthon. Concentration-dependent activation of CBP and p300 by TTK21 was tested in gel fluorography studies (Fig. $1 B$ ) and filter-binding assays (Fig. $1 C, D$ ). The compound could efficiently activate the CBP HAT activity in a concentration-dependent manner, with a maximal activation at 250-275 $\mu \mathrm{M}$ (Fig. $1 B, C$ ) compared with the control solvent, DMSO. As expected, TTK21 activated the HAT activity of the functional ortholog of CBP, p300, to approximately the same extent at the maximal concentration of $275 \mu \mathrm{M}$ compared with control (Fig. $1 B, D$ ). As revealed in the highly purified in vitro assay system, both CBP and p300 predominantly acetylated the core histones $\mathrm{H} 3$ and $\mathrm{H} 4$ (Fig. $1 B$ ). However, although $\mathrm{H} 2 \mathrm{~B}$ and $\mathrm{H} 2 \mathrm{~A}$ core histones have been described as $\mathrm{CBP}$ targets in vivo, especially in the brain (Valor et al., 2011), we could not detect their acetylation in vitro. The activation of p300/CBP HAT activity could be achieved by several means, including the induction of auto-acetylation. The trans-auto-acetylation of p300/CBP, which is regulated by several protein factors and posttranslational modifications of the enzymes, induces the p300/ CBP HAT activity (Arif et al., 2010 and references therein). We therefore performed an auto-acetylation assay on full-length recombinant p300 with increasing concentrations of TTK21. As depicted in Figure 1E, TTK21 significantly induced autoacetylation of p300 at $100 \mu \mathrm{M}$ concentration compared with DMSO. Increase in the concentration of TTK21 (up to $500 \mu \mathrm{M}$ ) did not induce further auto-acetylation.

\section{Covalently conjugated CSP-TTK21 efficiently enters} membranes and induces HAT activation in living cells

As for its parent compound, CTPB, TTK21 is poorly permeable to living cells. HeLa cells were treated with increasing concentrations $(50,100,200$, and $275 \mu \mathrm{M})$ of TTK 21 and sodium butyrate, a permeant $\mathrm{HDAC}$ inhibitor $(5 \mathrm{~mm} \mathrm{NaBu})$, was used as positive control. Histone acetylation levels were measured after $24 \mathrm{~h}$. Western blot analysis using antibody against acetylated-H3K14 showed no significant alteration of histone $\mathrm{H} 3$ acetylation in response to TTK21 treatment (Fig. 2A, compare lanes 3-6 with the no treatment control lane 1 or the DMSO vehicle lane 2), whereas $\mathrm{NaBu}$ indeed activated $\mathrm{H} 3$ acetylation (Fig. 2A, lane 7). These data suggest the inability of the molecule to enter into mammalian cells. Therefore, TTK21 was conjugated to a glucose-derived CSP that is self-fluorescent and permeable to mammalian cells (Selvi et al., 2008). For the chemical conjugation, the functional groups present on the surface of CSP were used as described in the Materials and Methods section to covalently bind TTK21 and the CSP nanoparticle (Fig. 2B). The conjugation was confirmed by infrared spectroscopy and energy-dispersive $\mathrm{x}$-ray spectroscopy analysis (Fig. 2C,D, respectively). Infrared spectroscopy showed bands specific for the functional groups for TTK21, whereas specific peak for fluorine was found in CSP-TTK21, which is present in the $\mathrm{CF}_{3}$ group of TTK21. The electron microscopic images of CSP-TTK21 showed that, upon conjugation, the spherical shape of the nanoparticles was conserved (Fig. 2E). To investigate whether the covalent conjugation with CSP could enable TTK2 1 to enter mammalian cells, SHSY-5Y cells were either treated with CSP $(50 \mu \mathrm{g} / \mathrm{ml})$ or CSP-TTK21 (50 $\mu \mathrm{g} / \mathrm{ml})$ for 6,12 , or $24 \mathrm{~h}$. Immunoblotting analysis was performed on purified histones using an antibody against acetylated-H3K14. Enhancement of H3K14ac was observed over time in CSP-TTK21 (compare Fig. 2F, lanes 4-6 with lanes 1-3). Maximum acetylated H3K14levels were observed upon $12 \mathrm{~h}$ of CSP-TTK21 treatment (Fig. 2F). CSP-TTK21-induced acetylated H3K14 was further confirmed by immunofluorescence performed on CSP- and CSP-TTK21-treated SHSY-5Y cells (Fig. 2G). These findings suggested that although TTK21 itself cannot enter the living cells, the nanoparticle-conjugated material CSP-TTK21 could cross the mammalian cell membranes (including nuclear membranes) to induce histone hyperacetylation.

\section{CSP-TTK21 located in the brain induces histone acetylation in the frontal cortex and dorsal hippocampus}

The glucose-derived CSPs possess the unique ability to cross the blood-brain barrier in mice (Selvi et al., 2008; Selvi et al., 2012). Therefore, we next investigated the presence of CSP-TTK21 in different organs after intraperitoneal administration of CSPTTK21 (20 mg/kg). After $1 \mathrm{~d}$, brain, liver, lungs, kidney, and spleen tissue were isolated, fixed with paraformaldehyde, and processed for fluorescence imaging. The self-fluorescent CSP molecule could be observed on 5 - $\mu$ m-thick sections and its nuclear localization was counted in the different tissues (Fig. 3A). CSP-TTK21 was detected predominantly in the brain, liver, and spleen. It was mostly absent in the lungs and undetectable in the kidneys (Fig. 3A). We further investigated the retention time in liver and spleen and found that CSP content was dramatically decreased after $3 \mathrm{~d}$ and almost undetectable after $7 \mathrm{~d}$ (Fig. 3 B, C), showing a rapid turnover of the CSP-coupled molecule in these peripheral organs. We next performed a time course study on CSP-TTK21 retention in the brain $(1,3,7,14$, and $21 \mathrm{~d}$ ) after intraperitoneal administration. Typical fluorescence microscopy imaging of the cortical area is presented in Figure $3 D$ for days 1 
A

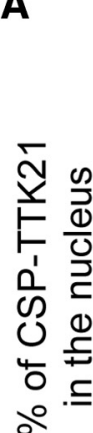

${ }^{25}$

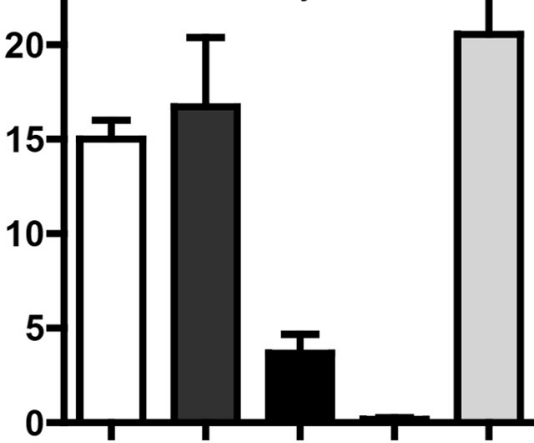

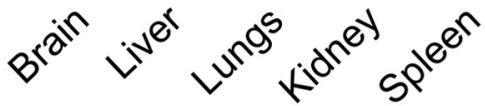

D CSP
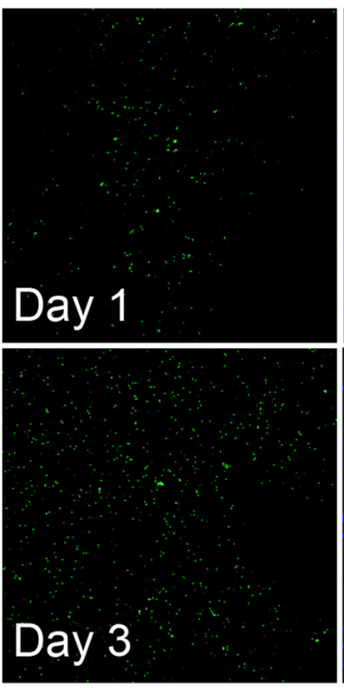

F

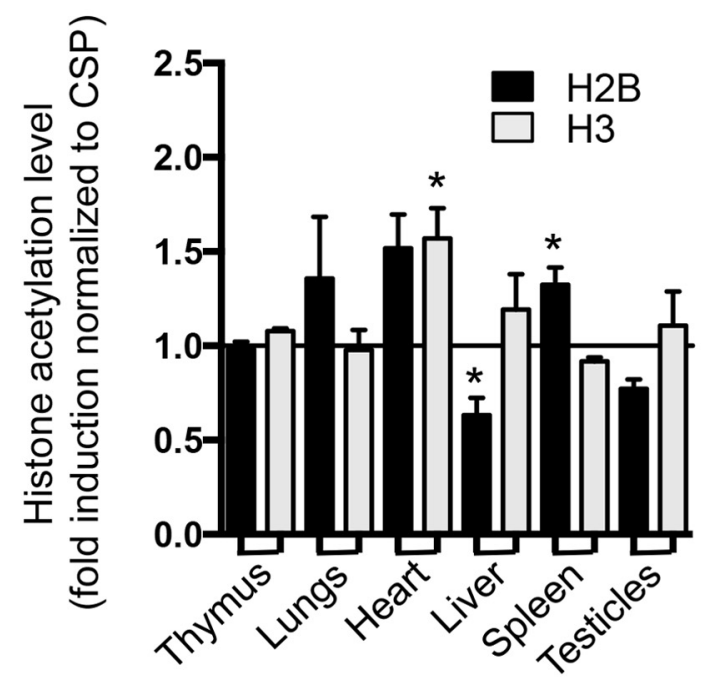

B

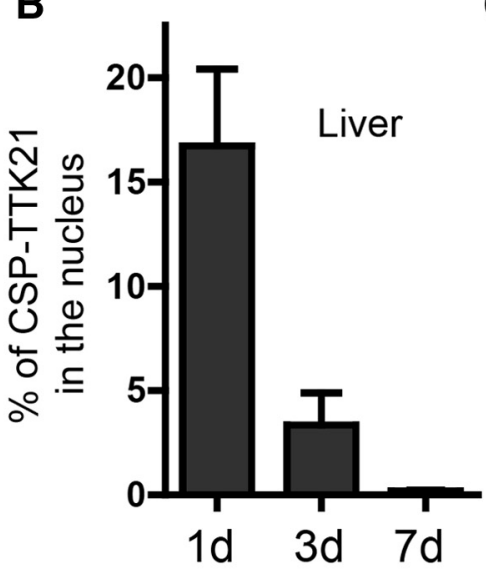

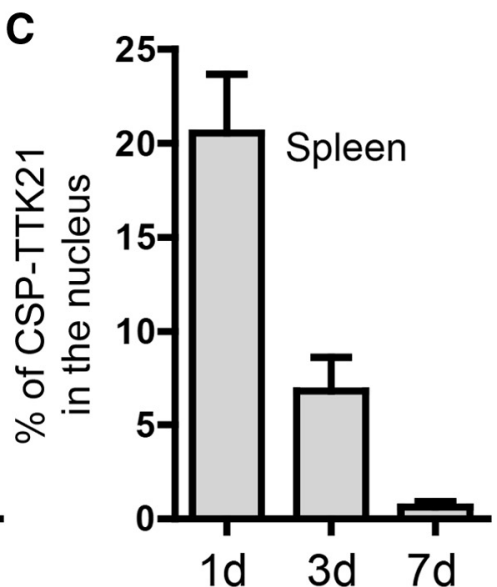

E
Merge

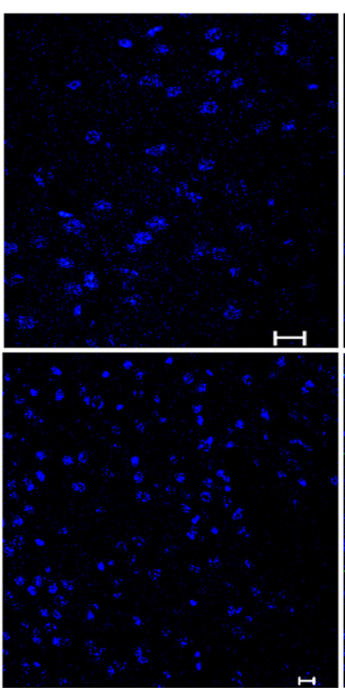

G

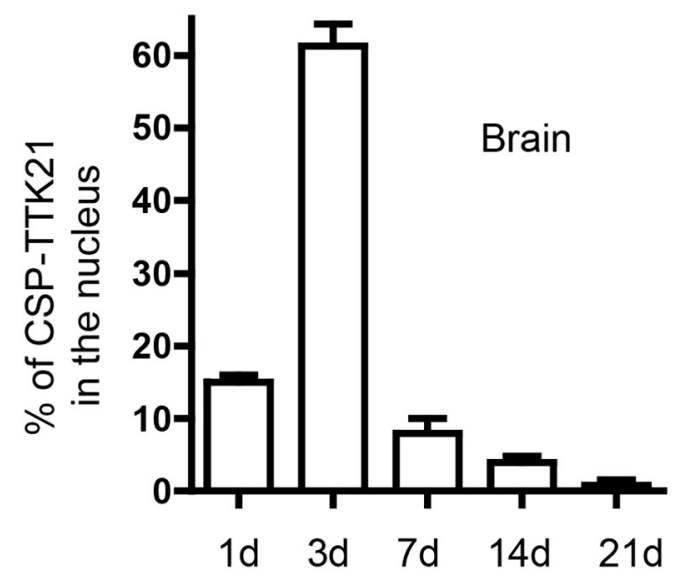

Figure 3. : (SP-TTK21 is located in the brain after a single intraperitoneal (i.p.) injection. $\boldsymbol{A}$, Localization of CSP-TTK21 in different organs of mice $1 \mathrm{~d}$ after an i.p. injection. Mice ( $n=5$ ) were injected with 20 mg/kg CSP-TTK21 and killed $24 \mathrm{~h}$ later. Brain, liver, lungs, kidney, and spleen were isolated and processed for histochemistry. CSP-TTK21 was detected by excitation at 514 nm. Nucleus of the cells in various tissues was stained with Hoechst. Histograms represent the quantification of the percentage of cells containing intranuclear CSP-TTK21. After $1 \mathrm{~d}$, CSP-TTK21 molecules are mainly found in the brain, liver, and spleen. $\boldsymbol{B}, \boldsymbol{C}$, Time-dependent presence of CSP-TTK21 in mice liver (B) and spleen ( $\boldsymbol{C})$ after a single i.p. injection. Same as in $\boldsymbol{A}$, except that 3 groups of mice were used $(n=3)$ and killed at different days after injection as noted $(1,3$, and $7 \mathrm{~d})$. CSP-TTK21 molecules levels are largely reduced $3 \mathrm{~d}$ after injection and almost absent after $7 \mathrm{~d}$. $\boldsymbol{D}$, $\boldsymbol{E}$, Time-dependent presence of CSP-TTK21 in mice brain after a single i.p. injection. Five groups of mice $(n=3)$ that were used $(n=3)$ and killed at different days after (Figure legend continues.) 
and 3, with the inset showing nuclear localization. Quantification of intranuclear CSP for the whole time course is represented in Figure $3 E$. In contrast to liver and spleen, we found that the percentage of nuclear-located CSP-TTK21 molecules was dramatically elevated $3 \mathrm{~d}$ after the intraperitoneal injection $(61 \%$ for day 3 compared with $15 \%$ for day $1 ; p=0.0001$ at day 3 relative to all the other days, one-way ANOVA followed by Newman-Keuls multiple-comparison test). From day 7 onwards, a gradual decrease of CSPTTK21 in the brain tissue was observed and, at day 21, almost no nanoparticle could be detected in nuclei (Fig. 3E). To further establish the activity of the HAT activator molecule associated with its distribution in the body, we dissected several peripheral organs on a group of CSP- and CSP-TTK21-injected mice (20 mg/kg; $n=4-6) 3 \mathrm{~d}$ after its intraperitoneal administration and analyzed histone H3K9K14 and H2B N-terminus acetylation by Western blot (Fig. $3 F$ ). We found a significant increase in $\mathrm{H} 2 \mathrm{~B}$ tetraacetylation in response to CSP-TTK21 in the spleen ( $p=0.0284)$; a trend to increase was observed in the heart ( $p=$ 0.0610 ) and a significant decrease was measured in the liver $(p=0.0193)$. $\mathrm{H} 3 \mathrm{~K} 9 \mathrm{~K} 14 \mathrm{ac}$ was found significantly increased only in the heart $(p=0.0372)$. Therefore, it seems that the CSP-driven activator displays some preference in the heart and the spleen, the major effect being 1.5-fold, and no acetylation was measured in the thymus, lungs, or testicles. Clearance of the molecule observed in the spleen was almost complete within $7 \mathrm{~d}$ (Fig. 3C) and the animals did not show any apparent behavioral or physiological abnormalities throughout this time, suggesting the nontoxic nature of CSP-TTK21 in the mouse system. We then assessed the efficacy of the HAT activator in different parts of the brain. Several brain regions were thoroughly dissected (Fig. $3 G$ ) and analyzed as in Figure 3F. The frontal cortex was the main region displaying the acetylated histones $\mathrm{H} 2 \mathrm{~B}$ ( $p=$ $0.0052)$ and $\mathrm{H} 3(p=0.0008)$, levels reaching approximately a 2 -fold increase. H4K12 acetylation was also significantly activated in this brain region by 1.4 -fold $\left({ }^{*} p=0.05\right)$, whereas $\mathrm{H} 2 \mathrm{AK} 5$

$\leftarrow$

(Figure legend continued.) injection as noted (1, 3, 7, 14, and $21 \mathrm{~d})$. Typical photographs for days 1 and 3 are shown (D). Magnified image of the nucleus from days 1 and 3 showing localization of (SP-TTK21 in the nuclei (inset of the respective figures). Scale bar, $10 \mu \mathrm{m} . \boldsymbol{E}$, Quantification of the percentage of cells containing intranuclear CSP-TTK21. Note that large amounts of CSP-TTK21 molecules are located in the nuclei of brain cells at $3 \mathrm{~d}$ after injection and that the molecules are rapidly cleared out of cells. $\boldsymbol{F}, \boldsymbol{G}$, Three days after i.p. injection of either CSP alone or CSP-TTK21 (20 mg/kg body weight), different organs or brain subregions were dissected out and Western blots were performed on total protein extracts with acetylated H2B or $\mathrm{H} 3$ and total $\mathrm{H} 2 \mathrm{~B}$. Quantification of acetylated histone levels is shown relative to the total amount of the H2B $(n=4-6)$. Student's $t$ test, ${ }^{*} p<0.05$ and ${ }^{* *} p<0.01$ compared with CSP control. \#Close to significance. Cx indicates cortex; $d$, dorsal; Hippo, hippocampus; v, ventral; $p$, para. levels remained unchanged in response to CSP-TTK21 (data not shown). $\mathrm{H} 2 \mathrm{~B}$ and $\mathrm{H} 3$ histone acetylation were significantly activated by the CSP-TTK21 molecule in the dorsal hippocampus (H2Bac, 1.39-fold, ${ }^{\star} p=0.0432$; H3ac, 1.47 -fold, $\left.{ }^{\star} p=0.0119\right)$ and brainstem (H2Bac, 1.72 -fold, ${ }^{*} p=0.001$; H3ac, $1,58,{ }^{\star} p=$ 0.0284 ), whereas a trend was measured for $\mathrm{H} 3 \mathrm{ac}$ in the striatum (dorsal, $p=0.0567$; ventral, 0.0542). Overall, these data show that the CSP-TTK21 molecule can affect different brain subregions and different tissues. This may be due to its mode of entry into mammalian cells described so far, which is ATP, clathrin, and glucose transporter dependent (Selvi et al., 2012). The exact mechanisms of this specificity remain to be established.

Because the dorsal hippocampus plays an important role in several brain functions and has specific structural features, we further measured the level of different acetylation histone marks in response to CSP-TTK21 of treated mice using immunohistochemistry (Fig. $4 A-C$ ). We found that acetylated-H2BK5 was increased after CSP-TTK21 treatment equally within the different area of the dorsal hippocampus (CA1, CA3, and dentate gyrus; Fig. 4A). The tetra-acetylated form of $\mathrm{H} 2 \mathrm{~B}$ and acetylated H3K14 were also equally increased and distributed in the dorsal hippocampus subregions, and representative confocal images focused on the dentate gyrus obtained after immunofluorescence labeling are shown (Fig. $4 B, C$ ).

These data demonstrate that the CSP-driven molecule displays HAT activation by acetylating several histone acetylation 
marks in important brain structures such as the hippocampus and the frontal cortex.

\section{HAT activation in vivo induces differentiation and maturation steps of adult hippocampal neurogenesis}

The hippocampus is a major neurogenic niche of the brain, neural progenitor cells being formed in the SGZ and further differentiating within the dentate gyrus (Kempermann, 2012). Having shown a significant effect of CSP-TTK21 on histone acetylation levels in the dorsal hippocampus at day 3 after injection, we investigated whether $\mathrm{CBP} / \mathrm{p} 300$ activation in vivo could affect adult neurogenesis. We performed immunohistochemistry studies on DCX, a marker of new, yet immature neurons in the adult brain, $3 \mathrm{~d}$ after injection of CSP or CSP-TTK21 (Fig. 5A-D, the timeline of the experimental protocol is shown on the upper right). Typically, $4-6$ sections were analyzed per animal $(n=3)$. Overall, a clear increase of dendritic branching was observed on the dorsal hippocampus in response to CSP-TTK21 (Fig. 5A), which was not accompanied by an increase of DCX-positive neurons over the $3 \mathrm{~d}$ (Fig. $5 B ; p=0.1311$ ). In average, new neurons showed a significant increase in the length of their dendritic trees (Fig. $5 C$; $\left.{ }^{*} p=0.0177\right)$. A thorough counting of specific areas within the dorsal dentate gyrus showed that DCX-positive neurons were particularly well branched in CSP-TTK21 compared with CSPtreated mice, especially in the vicinity of the dendrites' extremities (e.g., $120 \mu \mathrm{m}$ distance from the SGZ; Fig. 5D; CSP-TTK21 vs CSP, ${ }^{\star} p=0.0115$ at $60 \mu \mathrm{m} ;{ }^{\star} p=0.0270$ at $90 \mu \mathrm{m}$ and ${ }^{\star} p=$ 0.0389 at $120 \mu \mathrm{m} ; n=5 /$ animal). In view of their maturation status at the time of treatment, increased DCX labeling by CSPTTK21 is likely to result from activation of the maturation process of young neurons generated before the injection of the molecules. It was therefore interesting to further measure the effect of CSP-TTK21 on the proliferation of progenitors. One group of mice received a single injection of BrdU $(100 \mathrm{mg} / \mathrm{kg})$ $1.5 \mathrm{~d}$ after injection of the molecules (Fig. $5 F, G$ ). The mice were killed $2 \mathrm{~h}$ later, thus giving the net proliferation status of progenitors at that time. A typical image is shown in Figure $5 F$ and quantification is presented in Figure 5G. We measured a decreased number of BrdU-positive cells in CSP-TTK21-treated animals compared with CSP alone (31.4 vs 19.9 BrdU-positive cells, ${ }^{*} p=0.0383, n=4 /$ animal), suggesting an antiproliferative effect of the HAT activator. To determine the fate of these newly generated neurons, different time courses were investigated: $10 \mathrm{~d}$ (Fig. $5 H$ ) and $21 \mathrm{~d}$ (Fig. $5 I, J)$ after the molecule injection on different groups of mice. The timeline of CSP, CSP-TTK21, and BrdU administration is represented above the quantifications. Despite the first antiproliferative effect measured at day 1.5, an equal number of BrdU-positive cells was observed in CSP- and CSP-TTK21-treated mice at day 10, suggesting that progenitors survival slightly increased. Double immunolabeling with BrdU and DCX was performed $21 \mathrm{~d}$ after CSP-TTK21 injection and the number of BrdU-positive/DCX-positive neurons was counted throughout the dentate gyrus (hill included). We found that 75\% of the BrdU-positive cells were DCX-positive in both CSP and CSP-TTK21 conditions (Fig. 5I), suggesting that the HAT activator did not influence the fate of the progenitors. A representative image of BrdU-positive/DCX-positive neurons as typically found in the SGZ is shown in Figure 5J.

Finally, we evaluated several mature or immature cell type markers (neurons vs glial cells) by qRT-PCR at two time points: 1.5 and $3 \mathrm{~d}$ after injection (Fig. $5 \mathrm{~K}$ ). Because increased amounts of DCX proteins were observed by immunohistochemistry, DCX mRNA levels were measured and were found to be significantly increased at day 3 after injection $\left({ }^{*} p=0.0328, n=5-6\right)$. The TUC4 protein (TOAD [Turned On After Division]/ Ulip/CRMP) reaches its highest expression levels in early postmitotic neurons and, as is the case for DCX, is expressed in immature neurons, but not in neural progenitors or adult neurons (Quinn et al., 1999), and is therefore a good candidate for CSP-TTK21 activation. Nevertheless, TUC4 only tended to increase in response to CSPTTK21 treatment compared with CSP $(p=0.0988, n=5)$. However, both DCX and TUC4 were significantly increased at day 3 compared with day 1.5 after injection of CSP-TTK21 (\#p = $0.0121, n=5$ and $\# p=0.0377, n=5$, respectively). For glial markers, the immature glial protein vimentin showed a trend to be repressed compared with CSP at the early time point (day 1.5; $p=0.0542$ ), but remained unchanged at day 3 ( $p=0.5808$ ) (Fig. $5 K)$. Vimentin mRNAs were indeed lowered by $30 \%$ when day 1.5 was compared with day 3 ( $p=0.0371)$. GFAP levels remained unchanged whatever the comparison. The meaning of this early downregulation of vimentin is not known, but it is unlikely to play a major role because vimentin levels were unchanged at day 3. In addition, we previously observed no significant changes in the percentage of newly generated neuron after injection of the activator molecule among the BrdU-positive cells (Fig. $5 I, J$ ), so, by extension, no change in the number of glial cells was expected either.

\section{CSP-TTK21 induces neuroD1 and BDNF gene expression in the hippocampus by increasing chromatin acetylation of their promoters}

We next evaluated, using qRT-PCR, the expression of neuroD1 and $b n d f$, two genes that are associated with neuronal differentiation and maturation: neuroD1 is a key transcription factor essential for terminal differentiation of the granule cells in the hippocampus (Gao et al., 2009) and bdnf depletion studies targeted in the hippocampus have recently demonstrated its crucial role for the terminal differentiation of new neurons in the adult mice (Chan et al., 2008). We found a significant increase of neuroD1 mRNA as soon as $1.5 \mathrm{~d}$ after CSP-TTK21 injection in mice (1.34-fold, $p=0.0344, n=5)$, and the mean mRNA level was still larger, although not significantly, after $3 \mathrm{~d}$ (1.21-fold, $p=0.3876$, $n=5$; Fig. $6 A$ ). The $b d n f$ gene has a very complex structure that allows the production of different splice variants and, in the hippocampus, it is regulated through activation of different promoters, mainly I and IV (Lubin et al., 2008; Tian et al., 2009). Total (tot bdnf), exon I (bdnf_eI), and exon IV (bdnf_eIV) bdnf mRNA levels were measured in response to CSP-TTK21 (Fig. $6 B$ ). At day 1.5 after injection, total bdnf transcripts were already significantly increased by $>2$-fold in CSP-TTK21-treated animals compared with CSP controls ( ${ }^{* *} p=0.0041, n=5$ ), an effect mediated in part through bdnf I promoter activation (1.40-fold, $\left.{ }^{* *} p=0.0090, n=5\right)$. At this early time point, bdnf_eIV transcripts were not altered by the treatment $(p=0.2911, n=5)$. At day3, total bdnf transcripts were still significantly induced by CSP-TTK21 $\left({ }^{*} p=0.0352, n=5\right)$ compared with CSP, but less markedly than at day 1.5 (1.4- vs 2.32 -fold). Both bdnf_eI and bdnf_eIV transcripts were upregulated in response to CSPTTK21 (1.58-fold, ${ }^{*} p=0.0305$ and 1.52 -fold, ${ }^{*} p=0.0099$, respectively).

We next prepared the chromatin from dorsal hippocampi of mice $1.5 \mathrm{~d}$ after injection of CSP or CSP-TTK21 ( $n=3$ /group) to determine whether neuroD1 and bdnf promoters were enriched with acetylated-H2B histone. Gels from semiquantitative PCR analyses of promoters are shown in Figure $6 C$ and the quantification of immunoprecipitated DNA relative to its corresponding input is presented in Figure $6 D$. In good correlation with gene 
A Molecule

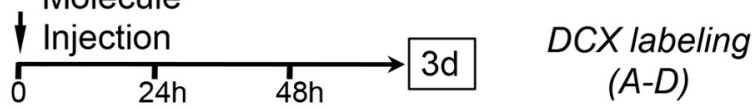

CSP

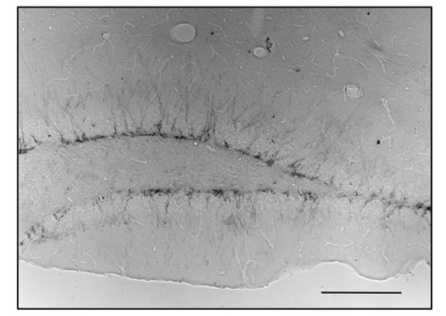

D

\section{CSP}

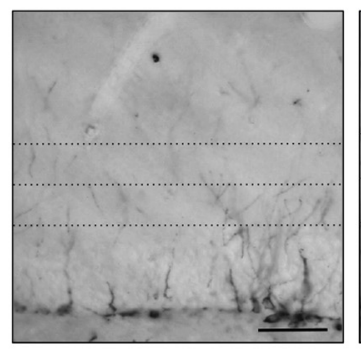

F

CSP

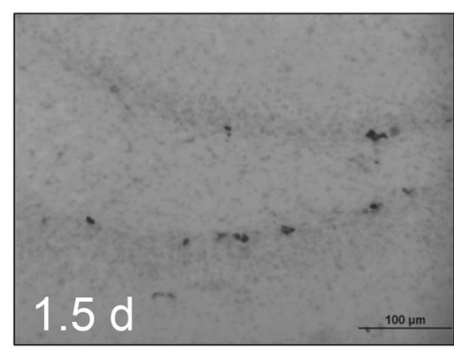

I Molecule

Injection

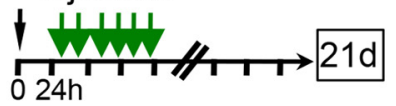

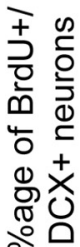

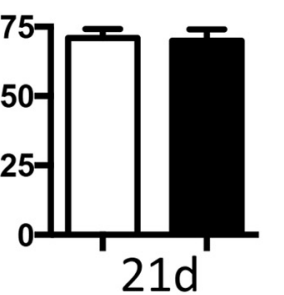

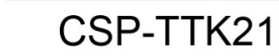

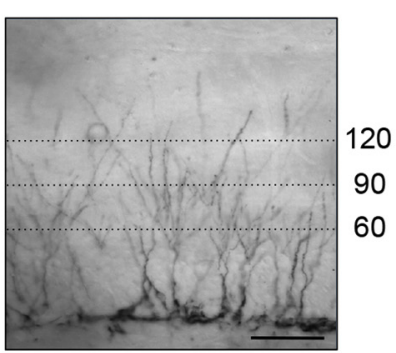

CSP-TTK21

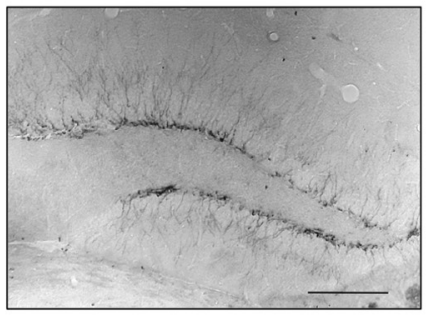

120

90

60

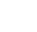

J

\section{BrdU}

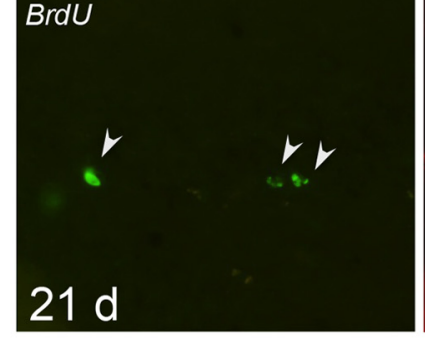

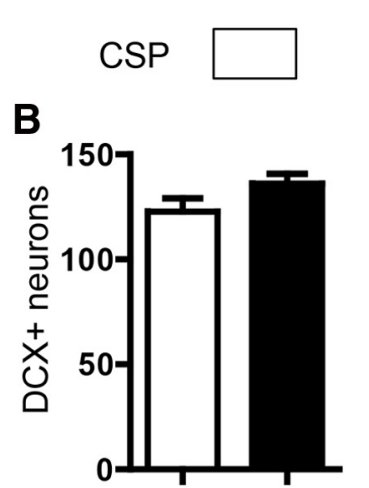

CSP-TTK21

C

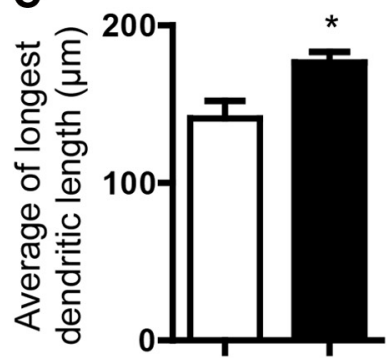

E

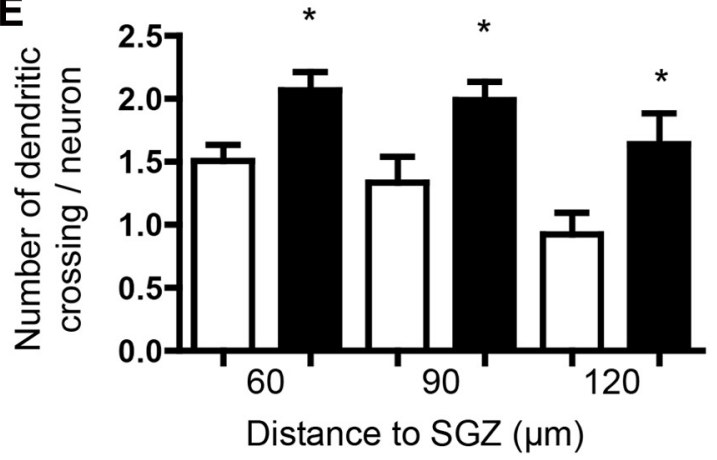

G

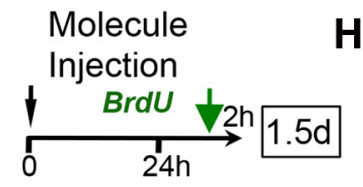

H Molecule Injection
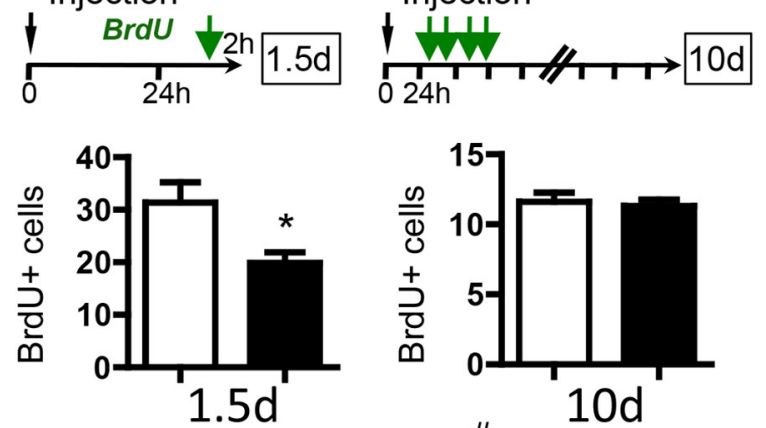

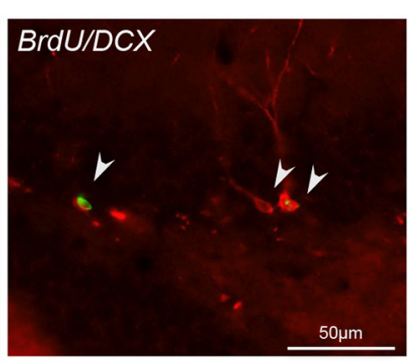

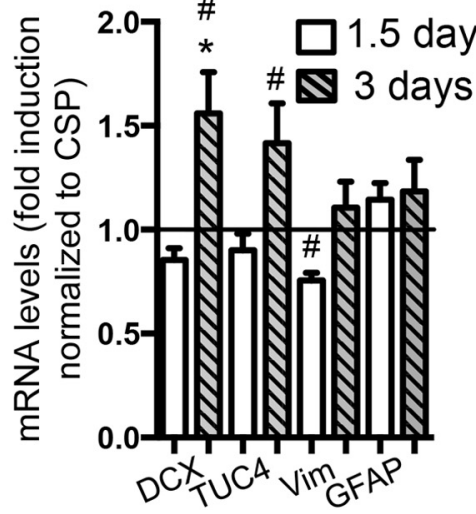

Figure 5. CSP-TTK21 stimulates the maturation step of adult neurogenesis in the SGZ of the dentate gyrus. $\boldsymbol{A}-\boldsymbol{D}$, Immunohistochemistry analysis of the dentate gyrus of mice $3 \mathrm{~d}$ after intraperitoneal injection of either CSP alone or CSP-TTK21 (20 mg/kg body weight) using an antibody against DCX followed by DAB staining. A typical photograph is shown ( $A$ ). Scale bars, $100 \mu \mathrm{m}$. The timeline for injection and euthanasia is shown. $\boldsymbol{B}$, Histograms representing the number of DCX-positive neurons per section (4-6 sections/animal). $\boldsymbol{C}$, The average of the longest dendrites associated to all DCX-positive new neurons within one hippocampus was calculated and is represented as a histogram for each condition (CSP: $141.1 \mu \mathrm{m}$ vs CSP-TTK21: $176.9 \mu \mathrm{m},{ }^{*} p=0.0177,4-6$ sections/animal). $\boldsymbol{D}$, Typical cropped image from $\boldsymbol{A}$ is shown, on which the number of dendrites crossing virtual lines drawn at 60,90 , and $120 \mu \mathrm{m}$ from the $S G Z$ was counted ( $n=5 \mathrm{images} /$ animal). $\boldsymbol{E}$, Histograms represent the dendritic crossing per DCX-positive neuron averaged from 3 animals. Student's $t$ test. ${ }^{*} p<0.05$. Scale bars, $100 \mu \mathrm{m}$. Note that dendritic branching is still dense at the very end of the dendrites in CSP-TTK21 compared with CSP treated mice. F-J, CSP-TTK21 effect on adult neurogenesis after BrdU injection (100 mg/kg). Different protocols have been performed to show proliferative and/or survival effects after $1.5 \mathrm{~d}(\boldsymbol{F}, \boldsymbol{G}), 10 \mathrm{~d}(\boldsymbol{H})$, or $21 \mathrm{~d}(\boldsymbol{I}, \boldsymbol{J})$. Protocols are schematically summarized above each quantitated histograms, in which the number of BrdU injections and their timing are represented by a green arrow $(\mathbf{G}-\boldsymbol{I})$. Representative images $(\boldsymbol{F})$ show that CSP-TTK21 exerts an antiproliferative effect on newly generated neurons at an early time point after injection (1.5 d; $n=3-4$ /group). Scale bars, $100 \mu \mathrm{m}$. H, A similar number of BrdU-positive neurons was counted in both CSP-and CSP-TTK21-treated mice ( $n=3 /$ group) (Figure legend continues.) 
expression studies (Fig. 6A,B), there was a significant enrichment in acetylated histone on the neuroD1 and bdnf PI promoters in response to CSP-TTK21 treatment, whereas acetylated histone at the bdnf PIV promoter remained unchanged. Therefore, our studies support a molecular link between the acetylation of $\mathrm{H} 2 \mathrm{~B}$ by the HAT activator molecule and the expression of neuroD1 and $b d n f$, two genes implicated in enhanced maturation and differentiation of adult neuronal progenitors in response to CSP-TTK21 injection.

Last, we verified that increased $b d n f$ gene expression was leading to the production of its precursor protein pro-BDNF in the dorsal hippocampus of CSP- and CSP-TTK21-treated mice 1.5 and $3 \mathrm{~d}$ after injection (Fig. 6E,F). We show that CSP-TTK21 induces a significant 1.5-fold increase in protein levels at both days (day 1.5: $p=0.0008$ and day $3: p=0.0015, n=5$ ), whereas GFAP and NeuN protein levels remained unchanged upon treatment. Therefore, increased $b d n f$ mRNA levels at both 1.5 and $3 \mathrm{~d}$ after injection could account for the increased pro-BDNF protein levels found at these time points.

\section{CSP-TTK21 treatment extends memory duration in adult mice}

Because CSP-TTK21 activates histone acetylation in the brain and differentiation of newly generated neurons, we further tested the HAT activator as a potential promnesic molecule in a hippocampus-dependent task taxing spatial reference memory. We first defined the retention profile of mice in our experimental room following a weak learning protocol of acquisition (Fig. 7A). Compared with a standard protocol of 5 training days or more, our mice $(n=30)$ were trained in the Morris water maze for only $3 \mathrm{~d}$ : they had to search the location of platform hidden at a fixed place. Latencies to reach the platform are shown in Figure 7A, left. There was a significant improvement of learning over the $3 \mathrm{~d}$ $\left(F_{(2,58)}=7.46 ; p<0.01\right)$. After acquisition, a 60 s probe test, for which the platform was removed, was given at postacquisition delays of 2,7 , or $14 \mathrm{~d}$ ( $n=10$ /group). The time spent in the target quadrant $(\mathrm{T})$ was compared with the average time spent in the 3 other quadrants $(\mathrm{O})$ (Fig. 7A, right). Despite mild learning, mice did significantly recall the platform location after $2 \mathrm{~d}$ of rest $\left({ }^{* *} p<0.0001\right)$ and even after $7 \mathrm{~d}\left({ }^{* *} p=0.0008\right)$. However, they had forgotten this location after $14 \mathrm{~d}(p=0.0728)$. We also compared whether the searching time in the target quadrant was significantly superior to that accounting for a random distribution of the swim track pattern ( $15 \mathrm{~s}$, solid line), which was the case for retention tested after $2(\# \# \#=0.0025), 7(\# p=0.0109)$, but not 14 ( $p=0.1160)$ days. Therefore, we further evaluated retention performance of new groups of mice treated with either CSP alone as control or CSP-TTK21 at two different time points (Fig. $7 B$ ). In this protocol, we made a single injection of the molecule $3 \mathrm{~d}$ before acquisition, so that when the training started (Acqui-

\footnotetext{
(Figure legend continued.) $10 \mathrm{~d}$ after the injections. I, J, CSP and CSP-TTK21-treated mice ( $n=3 /$ group) were injected with BrdU twice a day for $3 \mathrm{~d}$ and killed at day 21 for BrdU and DCX colabeling. The images shown in $J$ depict three BrdU-positive/DCX-positive neurons as typically observed in CSP-TTK21 mice. Scale bar, $50 \mu \mathrm{m}$. The same results were observed in the CSPtreated group. Quantification in Ishows that $\sim 75 \%$ of the all BrdU-positive cells counted in the dentate gyrus (hill included) are double labeled with DCX. $\boldsymbol{K}$, qRT-PCR analyses of mRNA levels in response to CSP and CSP-TTK21 treatment. Mice ( $n=5 /$ group) were treated and killed either 1.5 or $3 \mathrm{~d}$ after intraperitoneal injection as indicated. Data are represented as the fold induction by CSP-TTK21 normalized to CSP alone. mRNA quantities have been normalized with RNA polll levels measured in each sample. Student's $t$ test, ${ }^{*} p<0.05$ when CSP-TTK21 is compared with CSP alone; $\# p<0.05$ when CSP-TTK21 at day 3 is compared with CSP-TTK21 at day 1.5 .
}

sition A1), the hippocampus already displayed increased acetylation levels (Fig. 4), accelerated maturation of young adult neurons (Fig. 5A-D), and increased pro-BDNF expression (Fig. $6 F$ ). We tested retention after $2 \mathrm{~d}$, because at this retention time, performance can still be ameliorated despite mice already displaying searching scores above chance. Indeed, this mouse strain could reach an average of 30-33 s of focused search in the target quadrant after a regular 5-day training in our experimental room (data not shown). However, as seen in Figure $7 C$, right, whether treated with HAT activator (CSP-TTK21) or not (CSP alone), performance of the mice was similar: they were significantly increased in the target quadrant compared with the other quadrants $\left({ }^{* *} p=0.0001\right.$ for both CSP and CSP-TTK2 1 groups, $n=$ $10)$ and the search time in the target quadrant was significantly larger than chance $(\# \# \# p=0.0001$ for CSP and $\# \# \# p=0.0006$ for CSP-TTK21). Scores reached by CSP-TTK21-treated mice were equal to those of CSP-treated mice (23.6 vs $23.9 \mathrm{~s}$ in T). We also tested retention performance after $16 \mathrm{~d}$, a retention day at which searching scores of mice trained for $3 \mathrm{~d}$ are usually not different from chance. Figure $7 D$ shows that CSP-treated mice $(n=12)$ performed as well as nontreated mice (shown in Fig. 7A, $14 \mathrm{~d}$ ); the search did not focus on the target quadrant and it was not different from chance in the target quadrant. However, CSPTTK21-treated mice did show a significant search in the target quadrant compared with others $\left({ }^{* * *} p=0.001\right)$ and the searching score was above chance $(\# p=0.0117)$. CSP-TTK21 treatment had no effect on acquisition performance (Fig. $7 C, D$, left). ANOVA revealed a significant effect of day for each group (Fig. $7 C: F_{(2,36)}=9.06 ; p<0.001$; Figure $7 D: F_{(2,44)}=17.87 ; p<$ $0.00001)$, but no significant effect of treatment (Fig. $7 C: F_{(1,18)}=$ $0.35 ; p=0.55$; Fig. $\left.7 D: F_{(1,22)}=0.28 ; p=0.59\right)$. These data show that CSP-TTK21-induced HAT activation in mice affects the persistence of a spatial memory by extending the time during which this memory can be retrieved.

Finally, we measured the expression of several genes related to memory and hippocampal/neuronal excitability: Egr-1, Arc, cFos (Guzowski et al., 2001), CREB1 (Lopez de Armentia et al., 2007), Folsl2, and Nr4A2 (Hawk and Abel, 2011; Hawk et al., 2012) at the basal level (nonbehaving animals) and in response to CSPTTK21 compared with CSP alone (Fig. 8). None of the genes tested was altered at day 1.5. However, Nr4a2 and cFos showed a significant increase $3 \mathrm{~d}$ after injection compared with CSP controls $\left(1.48\right.$-fold, ${ }^{*} p=0.0410$ and 1.87 -fold, ${ }^{* *} p=0.0092$, respectively). cFos was also significantly induced at day 3 compared with day 1.5 (1.79-fold, \#\#p=0.0029). Fosl2 showed a nonsignificant trend to increase at day 3 compared with CSP controls (1.47-fold, $p=0.0948$ ) and it was significantly increased at day 3 compared with day 1.5 (1.9-fold, $\# p=0.0159)$. CREB1 presented a nonsignificant induction $(p=0.1189)$ and Egr-1 and Arc levels remained unchanged after $\mathrm{CBP} / \mathrm{p} 300$ activation.

\section{Discussion}

In this study, we synthesized a novel HAT activator molecule (CSPTTK21) and demonstrated its ability to improve some brain functions in vivo. We first showed that TTK21 activates CBP and p300 in vitro. Covalently bound to a CSP nanosphere, it increased histone acetylation in several brain regions, including the frontal cortex and the dorsal hippocampus, without apparent toxicity. Functional analyses showed that CSP-TTK21 promoted differentiation and maturation of young adult hippocampal neurons and improved long-term retention of a spatial memory. Because pharmacological activation of $\mathrm{CBP} / \mathrm{p} 300$ has never been achieved in vivo, mostly because of the poor permeability of HAT activators (Selvi et al., 2008), 
A
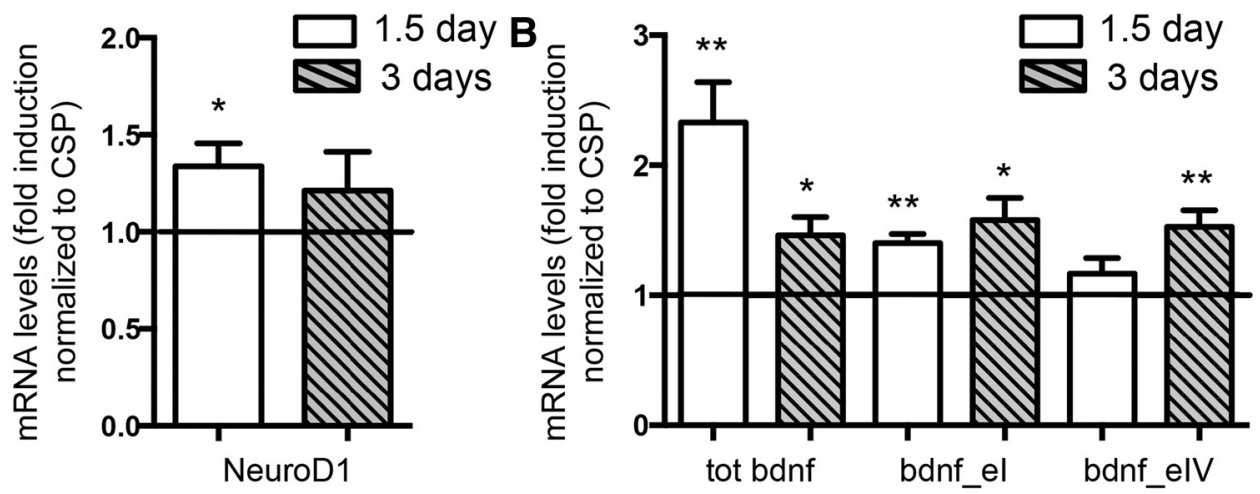

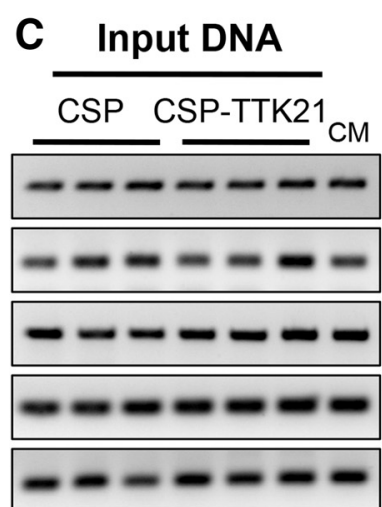

$\mathbf{E}$

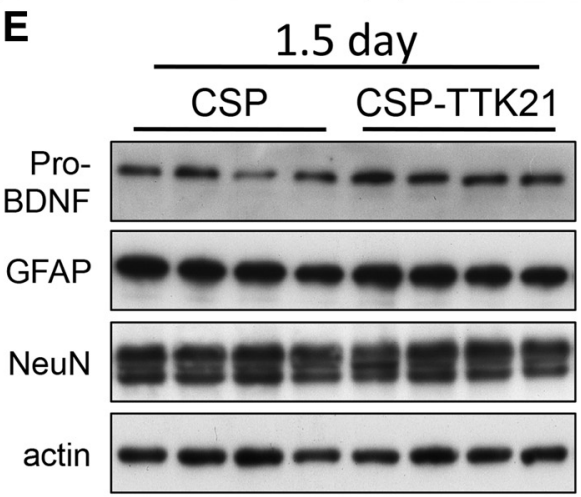

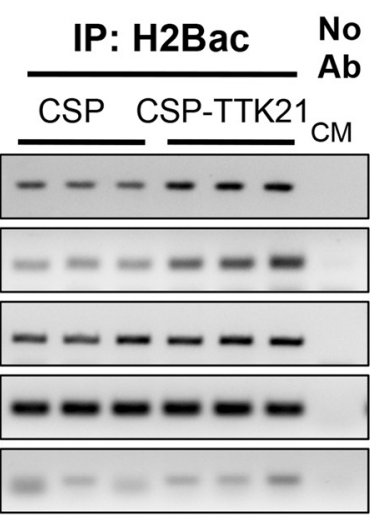

No

$\mathbf{F}$
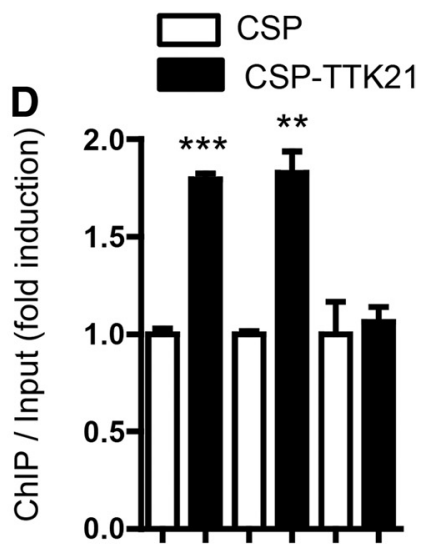

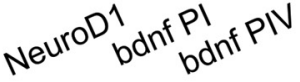

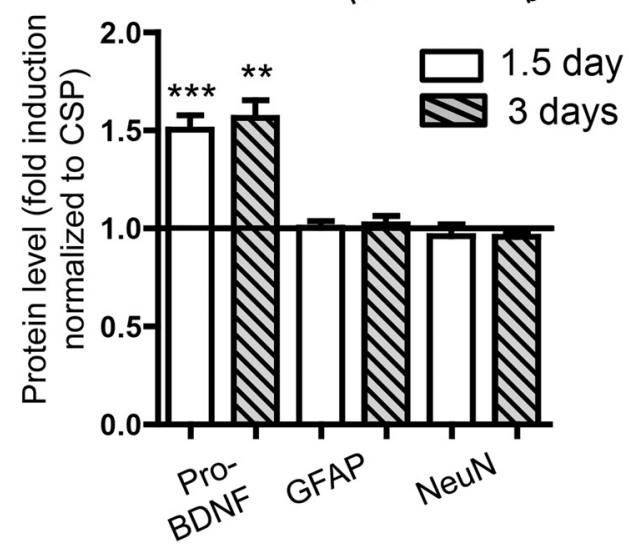

Figure 6. CSP-TTK21 stimulates neuroD1 and bdnf expression in the hippocampus. $A, B, q R T-P C R$ analyses of mRNA levels in response to CSP and (SP-TTK21 treatment. Mice $(n=5 /$ group) were treated and killed either 1.5 or $3 \mathrm{~d}$ after intraperitoneal injection as indicated. Data are represented as the fold induction by CSP-TTK21 normalized to CSP alone. mRNA quantities have been normalized with RNA polll levels measured in each sample. Student's $t$ test, ${ }^{*} p<0.05,{ }^{* *} p<0.01$, when CSP-TTK21 is compared with CSP alone. At day 1.5 after injection, neuroD1 mRNA levels are significantly increased in mice treated with the HAT activator $(A)$, and mRNA representative of total $B d n f$, in part through activation of its promoter I, but not of promoter IV. At day 3 , both bdnf_exon I and IV were upregulated by CSP-TTK21 treatment $(\boldsymbol{B})$. C, $\boldsymbol{D}$, Chromatin immunoprecipitation performed on dorsal hippocampus of mice injected with either CSP or CSP-TTK21 $(n=$ 3/group). Chromatin was isolated $1.5 \mathrm{~d}$ after molecule injection. Specific promoter targets were evaluated by semiquantitative PCR. Results are shown in triplicate $(\boldsymbol{C})$ with input DNA (left) and immunoprecipitated samples (right). CM indicates chromatin mix; № Ab, no primary antibody. $D$, Quantification of immunoprecipitated material relative to its input level is represented as the fold induction where the CSP-treated group is arbitrarily set at 1 . ${ }^{* *} p<0.01$ and ${ }^{*} p<0.05$ compared with CSP alone. $\boldsymbol{E}, \boldsymbol{F}$, Western blot analyses of proteins obtained from the dorsal hippocampi of mice treated with CSP or CSP-TT21 for either 1.5 or $3 \mathrm{~d}$. Pro-BDNF was significantly increased by the CBP/p300 activator, whereas the level of the glial (GFAP) and neuronal (NeuN) markers were not changed. Typical autoradiograms obtained for $1.5 \mathrm{~d}$ samples are shown $(\boldsymbol{E})$ and their quantification is shown in $\boldsymbol{F}$. Student's $t$ test, ${ }^{* * *} p<0.001$ and ${ }^{* *} p<0.01$ compared with CSP alone.

these results represent an important scientific advance and open new therapeutic options for brain diseases.

$\mathrm{CBP} / \mathrm{p} 300$ activation favors differentiation of newly generated neurons in the dorsal hippocampus

A main result of this study is the dramatic effect of CSP-TTK21 on the dendritic network only $3 \mathrm{~d}$ after injection. Whereas the number of DCX-labeled neurons was unchanged, there was an increase in dendritic length and arborization and in mRNAs of immature neuronal markers (DCX, TUC4; Fig. 5), suggesting that the HAT activator had an impact on young hippocampal neurons already generated before its injection and accelerated their maturation. It is likely that CSP-TTK21-induced expression of neuroD1 contributed to this rapid maturation. Indeed, neuroD-lacking mice present hippocampal granule progenitors failing to mature and having little dendritic arborization (Schwab 
A Acquisition
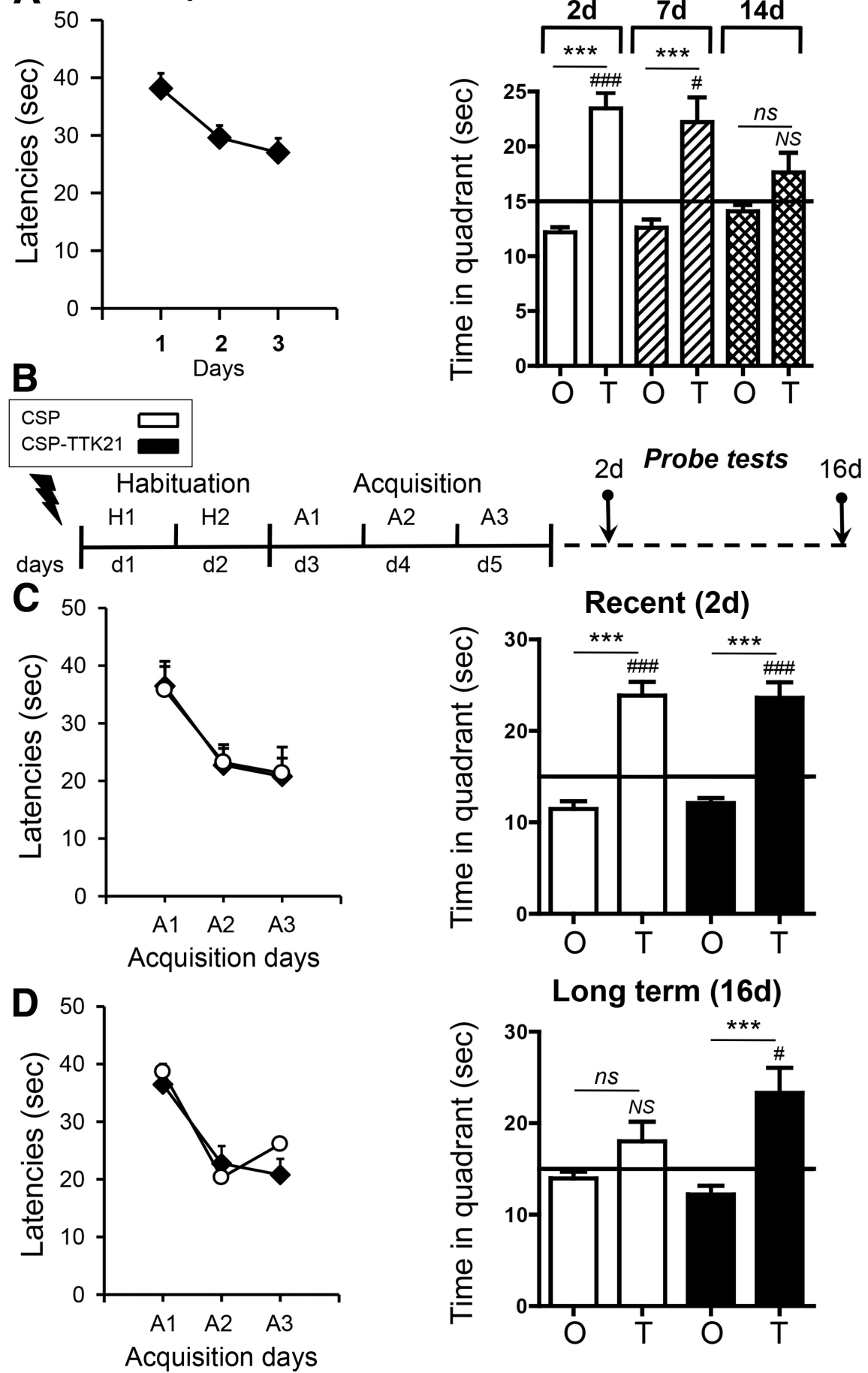

Figure 7. HAT activator-induced acetylation in the brain does not affect learning or recent memory, but extends memory duration. $\boldsymbol{A}$, Three groups of mice ( $n=10$ /group) were trained using a Morris water maze protocol for only $3 \mathrm{~d}$ to ensure a "weak learning" (i.e., leaving possibilities of amelioration). Left: Acquisition performance is shown as latencies to reach the platform. Right: Mice were tested for retention in a probe trial performed either after 2, 7, or $14 \mathrm{~d}$ after the last training session as indicated. The time spent in the target quadrant $(\mathrm{T})$ is represented; compare with the time spent in the average of the three other quadrants (0). The mice undergoing a weak learning show low but significant retention performance at day 2 and 7 and no recall of the platform location at day 14. $\boldsymbol{B}$, Timeline of CSP and CSP-TTK21 injection relative to the training protocol. $\boldsymbol{C}, \boldsymbol{D}$, Two groups of mice ( $n=20-22 /$ group) treated with either CSP or CSP-TTK21 were trained as in $A$ and tested for retention in a probe test either at $2 \mathrm{~d}$ for recent memory $(\boldsymbol{C})$ or $16 \mathrm{~d}$ for long-term memory $(\boldsymbol{D})$. Latencies are shown on the left. During training, the latencies decreased over sessions in a similar way in both treatment groups to be tested for retention at a 2-day postacquisition delay versus a 16-day delay. Retention scores are shown on the right. Retention of the platform location was lost after $16 \mathrm{~d}$ in CSP-treated mice, as expected from results obtained in nontreated mice $(\boldsymbol{B}, 14 \mathrm{~d})$, but CSP-TTK21 mice still displayed performance accounting for significant retention of the platform location. Student's $t$ test, ${ }^{* * *} p<0.001$ or ns (nonsignificant) comparing T with 0 . \#\# $<<$ 0.001 , \#p $<0.05$, or nonsignificant (NS) when T is compared with random performance ( $15 \mathrm{~s}$, solid line). et al., 2000). Concomitantly, there was a reduction of BrdU incorporation, demonstrating an antiproliferative effect of CSP-TTK21. These results are consistent with the fact that differentiation of progenitors follows different processes, such as blockade of the cell cycle, increase of differentiation markers, and production of structural proteins (Kempermann et al., 2004), so that progenitors cannot proliferate and differentiate at the same time. We report herein that these processes are most likely relevant to $\mathrm{CBP} / \mathrm{p} 300$ activation in vivo, which initiate the transcription of specific CBP-dependent genes such as neuroD1 (Sun et al., 2001). So far, CBP histone acetyltransferase activity was shown to regulate embryonic neural differentiation (Wang et al., 2010). Whether the same holds true in adults was unknown. However, whereas basal adult neurogenesis is not affected in $\mathrm{cbp}^{+/-}$ mice, it was shown that environmentinduced adult neurogenesis was significantly impaired in these mice, suggesting that it is extrinsically regulated by CBP function (Lopez-Atalaya et al., 2011). Therefore, our data support a role of CBP in adult neurogenesis, particularly in neuronal maturation and differentiation.

CSP-TTK21 upregulated the $b d n f$ gene and its precusor protein pro-BDNF (Fig. 6). BDNF increases dendritic complexity in the dentate gyrus (Danzer et al., 2002). BDNF depletion studies in the hippocampus revealed a proliferative state of granule progenitors and an increase of nondifferentiated DCX-positive neurons (Chan et al., 2008). Therefore, the antiproliferative effect of CSP-TTK 21 coupled to increased progenitor differentiation is in agreement with increased BDNF levels in the dorsal hippocampus.

Survival and differentiation processes are frequently altered during pathological aging, when persistent hippocampal proliferative capacity remains (Verret et al., 2007). Aberrant neurogenesis and unscheduled neuronal cell cycle events have been reported in animal models of Alzheimer's disease and in actual patients (Herrup, 2012). Manipulating endogenous progenitor cells could be useful for brain repair (Lie et al., 2004). Therefore, our HAT activator could open new horizons for treating neurodegenerative diseases.

\section{A new role for $\mathrm{CBP} / \mathrm{p} 300$ in the} persistence of memory

The dorsal hippocampus plays a major role in memory formation (Frankland and Bontempi, 2005). Many studies have established a role for CBP and p300 in 
memory processes (Barco, 2007; Oliveira et al., 2007; Barrett and Wood, 2008; Barrett et al., 2011; Oliveira et al., 2011). The activation of the CREB signaling pathway-a major target of $\mathrm{CBP} / \mathrm{p} 300$ - increases spatial memory strength in weakly trained animals (Sekeres et al., 2010). Therefore, a surprising result was that enhancing $\mathrm{CBP} / \mathrm{p} 300$ activity in the brain did not enhance spatial memory performance at a short postacquistion delay. CSP-TTK21 treatment, however, was able to extend memory vividness to $16 \mathrm{~d}$ after acquisition, a delay at which controls showed bad performance. In fact, it seems that most CBP mutants are deficient in some hippocampus-dependent forms of memory, particularly for object recognition, but not or poorly in spatial memory (Oike et al., 1999; Alarcón et al., 2004; Korzus et al., 2004; Valor et al., 2011). Similarly, conditional p300 knock-out mice exhibit normal spatial memory functions (Oliveira et al., 2011). In all of these studies, retention was tested at short postacquisition delays $(<24 \mathrm{~h})$. Therefore, whereas CBP is not critical for recent memory, it seems implicated in remote spatial memory formation. Consistent with this, $\mathrm{CBP} / \mathrm{p} 300$ activation results in increased BDNF expression, which is crucial for making memories durable (Bekinschtein et al., 2007; Bekinschtein et al., 2008).

How declarative memories persist for decades is a complex question. Consolidation involves reorganizations at synaptic and system levels, and stabilization of memories requires coordinated hippocampo-cortical interactions (Frankland and Bontempi, 2005; Winocur et al., 2010). We show herein that, in addition to activating histone acetylation in the dorsal hippocampus, CSPTTK21 injected systemically also induced histone acetylation in the frontal cortex and other brain parts (Fig. 3G). Therefore, because we applied our treatment just before training, one possibility is that CSP-TTK21 allowed a specific tagging in some cortical subregions, thereby reinforcing a hippocampo-cortical dialogue to form a persistent memory, as described recently (Lesburguères et al., 2011).

Adult hippocampal neurogenesis is required for hippocampusdependent memory, and new adult-generated neurons contribute to spatial memory updating and strengthening (Trouche et al., 2009). Young adult neurons, particularly those that mature after training, are important for remote memory, especially in spatial tasks (Goodman et al., 2010; Arruda-Carvalho et al., 2011). It is also hypothesized that newly formed neurons could facilitate pattern separation and spatial memory resolution/completion by tagging CA3 neurons (Deng et al., 2010; Aimone et al., 2011; Sahay et al., 2011). With our injection timing (3 d before training day 1), the CSP-TTK21-induced differentiation occurred on previously generated new neurons (1-3 weeks old) and therefore might have contributed to more appropriate integration of these young adult neurons within the memory-fixing circuitry at the time of training, an effect that is beneficial for memory (Goodman et al., 2010).

Ultimately, whether the effect on memory retention is relevant to the HAT activator effect on cortical and hippocampal regions or on adult neurogenesis remains to be investigated by more specific approaches.
A new therapeutic option for memory-related diseases?

In addition to their opposite modes of action, a major difference between HATs and HDACs is their recruitment to the chromatin loci. HDACs are usually part of corepressor complexes targeted to a specific locus by protein/protein interactions such as HDAC1 with MeCP2 (Jones et al., 1998; Nan et al., 1998), dnmt1 (Fuks et al., 2000), or PP1 (Koshibu et al., 2009). HATs such as CBP and p300, in addition to being part of large coactivator complexes, possess bromodomains so that they can be targeted to chromatin through interaction with acetylated histones (Yang, 2004). It is thus plausible that HAT induction may have functional consequences different from those of HDAC inhibition; they will not necessarily be on the same gene at the same time. In addition, specific histone marks are acetylated during memory formation (Bousiges et al., 2013, Peixoto and Abel, 2013), marks that are more reliably performed by activating the writers (HATs) than blocking the erasers (HDACs). In nonbehaving animals, CSPTTK21 was able to activate specific transcriptional programs related to differentiation (Neuro D1, DCX, TUC4, BDNF), neuronal excitability (cFos), or memory (fosl2, Nr4a2), but transcription was not activated randomly because Egr-1 or Arc was not responsive to CBP/p300 HAT activation (Fig. 8).

Transcriptional dysfunctions have been reported in many neurodegenerative diseases and HDAC inhibitors are widely used in animal models to increase acetylation levels and reestablish genetic programs in the brain (Kazantsev and Thompson, 2008; Gräff et al., 2011). In particular, HDAC inhibitors preserve memory function or ameliorate the pathological condition in animal models of Alzheimer's disease (Ricobaraza et al., 2009; Kilgore et al., 2010; Ricobaraza et al., 2011; Govindarajan et al., 2011; Ricobaraza et al., 2012). Although recent progress has been made in deciphering the role of specific HDACs in learning and memory functions (Guan et al., 2009; McQuown and Wood, 2011; BahariJavan et al., 2012; Agis-Balboa et al., 2013) and in adult neurogenesis (Jawerka et al., 2010), HDACs represent a large family of isoforms and it is hard to predict which ones to target in a particular pathological context (Fischer et al., 2010). Furthermore, the development of effective treatments based on HDAC inhibition is limited by a lack of specificity of currently available molecules that often block many, if not all, HDAC isoforms (Khan et al., 
2008). The data presented here open, for the first time, a new era of research to investigate the $\mathrm{CBP} / \mathrm{p} 300$ activation function in the brain in vivo. As an alternative to blocking HDACs, we propose a direct stimulation of acetyltransferase function, which could have important implications in terms of therapeutic options for neurodegenerative diseases, in which increasing the survival and maturation of endogenous progenitor cells may benefit functional recovery.

\section{References}

Agis-Balboa RC, Pavelka Z, Kerimoglu C, Fischer A (2013) Loss of HDAC5 impairs memory function: implications for Alzheimer's disease. J Alzheimers Dis 33:35-44. CrossRef Medline

Aimone JB, Deng W, Gage FH (2011) Resolving new memories: a critical look at the dentate gyrus, adult neurogenesis, and pattern separation. Neuron 70:589-596. CrossRef Medline

Alarcón JM, Malleret G, Touzani K, Vronskaya S, Ishii S, Kandel ER, Barco A (2004) Chromatin acetylation, memory, and LTP are impaired in $\mathrm{CBP}+$ /- mice: a model for the cognitive deficit in Rubinstein-Taybi syndrome and its amelioration. Neuron 42:947-959. CrossRef Medline

Arif M, Vedamurthy BM, Choudhari R, Ostwal YB, Mantelingu K, Kodaganur GS, Kundu TK (2010) Nitric oxide-mediated histone hyperacetylation in oral cancer: target for a water-soluble HAT inhibitor, CTK7A. Chem Biol 17:903-913. CrossRef Medline

Arruda-Carvalho M, Sakaguchi M, Akers KG, Josselyn SA, Frankland PW (2011) Posttraining ablation of adult-generated neurons degrades previously acquired memories. J Neurosci 31:15113-15127. CrossRef Medline

Bahari-Javan S, Maddalena A, Kerimoglu C, Wittnam J, Held T, Bähr M, Burkhardt S, Delalle I, Kügler S, Fischer A, Sananbenesi F (2012) HDAC1 regulates fear extinction in mice. J Neurosci 32:5062-5073. CrossRef Medline

Balasubramanyam K, Swaminathan V, Ranganathan A, Kundu TK (2003) Small molecule modulators of histone acetyltransferase p300. J Biol Chem 278:19134-19140. CrossRef Medline

Barco A (2007) The Rubinstein-Taybi syndrome: modeling mental impairment in the mouse. Genes Brain Behav 6:32-39. CrossRef Medline

Barrett RM, Wood MA (2008) Beyond transcription factors: the role of chromatin modifying enzymes in regulating transcription required for memory. Learn Mem 15:460-467. CrossRef Medline

Barrett RM, Malvaez M, Kramar E, Matheos DP, Arrizon A, Cabrera SM, Lynch G, Greene RW, Wood MA (2011) Hippocampal focal knockout of CBP affects specific histone modifications, long-term potentiation, and long-term memory. Neuropsychopharmacology 36:1545-1556. CrossRef Medline

Bekinschtein P, Cammarota M, Igaz LM, Bevilaqua LR, Izquierdo I, Medina JH (2007) Persistence of long-term memory storage requires a late protein synthesis- and BDNF-dependent phase in the hippocampus. Neuron 53:261-277. CrossRef Medline

Bekinschtein P, Cammarota M, Katche C, Slipczuk L, Rossato JI, Goldin A, Izquierdo I, Medina JH (2008) BDNF is essential to promote persistence of long-term memory storage. Proc Natl Acad Sci U S A 105:2711-2716. CrossRef Medline

Bousiges O, Vasconcelos AP, Neidl R, Cosquer B, Herbeaux K, Panteleeva I, Loeffler JP, Cassel JC, Boutillier AL (2010) Spatial memory consolidation is associated with induction of several lysine-acetyltransferase (histone acetyltransferase) expression levels and $\mathrm{H} 2 \mathrm{~B} / \mathrm{H} 4$ acetylationdependent transcriptional events in the rat hippocampus. Neuropsychopharmacology 35:2521-2537. CrossRef Medline

Bousiges O, Neidl R, Majchrzak M, Muller MA, Barbelivien A, Pereira de Vasconcelos A, Schneider A, Loeffler JP, Cassel JC, Boutillier AL (2013) Detection of histone acetylation levels in the dorsal hippocampus reveals early tagging on specific residues of $\mathrm{H} 2 \mathrm{~B}$ and $\mathrm{H} 4$ histones in response to learning. PloS One 8:e57816. CrossRef Medline

Caccamo A, Maldonado MA, Bokov AF, Majumder S, Oddo S (2010) CBP gene transfer increases BDNF levels and ameliorates learning and memory deficits in a mouse model of Alzheimer's disease. Proc Natl Acad Sci U S A 107:22687-22692. CrossRef Medline

Chan JP, Cordeira J, Calderon GA, Iyer LK, Rios M (2008) Depletion of central BDNF in mice impedes terminal differentiation of new granule neurons in the adult hippocampus. Mol Cell Neurosci 39:372-383. CrossRef Medline
Chen G, Zou X, Watanabe H, van Deursen JM, Shen J (2010) CREB binding protein is required for both short-term and long-term memory formation. J Neurosci 30:13066-13077. CrossRef Medline

Danzer SC, Crooks KR, Lo DC, McNamara JO (2002) Increased expression of brain-derived neurotrophic factor induces formation of basal dendrites and axonal branching in dentate granule cells in hippocampal explant cultures. J Neurosci 22:9754-9763. Medline

Deng W, Aimone JB, Gage FH (2010) New neurons and new memories: how does adult hippocampal neurogenesis affect learning and memory? Nat Rev Neurosci 11:339-350. CrossRef Medline

Fischer A, Sananbenesi F, Mungenast A, Tsai LH (2010) Targeting the correct $\mathrm{HDAC}(\mathrm{s})$ to treat cognitive disorders. Trends Pharmacol Sci 31:605-617. CrossRef Medline

Frankland PW, Bontempi B (2005) The organization of recent and remote memories. Nat Rev Neurosci 6:119-130. CrossRef Medline

Fuks F, Burgers WA, Brehm A, Hughes-Davies L, Kouzarides T (2000) DNA methyltransferase Dnmt 1 associates with histone deacetylase activity. Nat Genet 24:88-91. CrossRef Medline

Gao Z, Ure K, Ables JL, Lagace DC, Nave KA, Goebbels S, Eisch AJ, Hsieh J (2009) Neurod1 is essential for the survival and maturation of adultborn neurons. Nat Neurosci 12:1090-1092. CrossRef Medline

Goodman T, Trouche S, Massou I, Verret L, Zerwas M, Roullet P, Rampon C (2010) Young hippocampal neurons are critical for recent and remote spatial memory in adult mice. Neuroscience 171:769-778. CrossRef Medline

Govindarajan N, Agis-Balboa RC, Walter J, Sananbenesi F, Fischer A (2011) Sodium butyrate improves memory function in an Alzheimer's disease mouse model when administered at an advanced stage of disease progression. J Alzheimers Dis 26:187-197. CrossRef Medline

Gräff J, Kim D, Dobbin MM, Tsai LH (2011) Epigenetic regulation of gene expression in physiological and pathological brain processes. Physiol Rev 91:603-649. CrossRef Medline

Gräff J, Rei D, Guan JS, Wang WY, Seo J, Hennig KM, Nieland TJ, Fass DM, Kao PF, Kahn M, Su SC, Samiei A, Joseph N, Haggarty SJ, Delalle I, Tsai LH (2012) An epigenetic blockade of cognitive functions in the neurodegenerating brain. Nature 483:222-226. CrossRef Medline

Guan JS, Haggarty SJ, Giacometti E, Dannenberg JH, Joseph N, Gao J, Nieland TJ, Zhou Y, Wang X, Mazitschek R, Bradner JE, DePinho RA, Jaenisch R, Tsai LH (2009) HDAC2 negatively regulates memory formation and synaptic plasticity. Nature 459:55-60. CrossRef Medline

Guzowski JF, Setlow B, Wagner EK, McGaugh JL (2001) Experiencedependent gene expression in the rat hippocampus after spatial learning: a comparison of the immediate-early genes Arc, c-fos, and zif268. J Neurosci 21:5089-5098. Medline

Hawk JD, Abel T (2011) The role of NR4A transcription factors in memory formation. Brain research bulletin 85:21-29. CrossRef Medline

Hawk JD, Bookout AL, Poplawski SG, Bridi M, Rao AJ, Sulewski ME, Kroener BT, Manglesdorf DJ, Abel T (2012) NR4A nuclear receptors support memory enhancement by histone deacetylase inhibitors. J Clin Invest 122:3593-3602. CrossRef Medline

Herrup K (2012) The contributions of unscheduled neuronal cell cycle events to the death of neurons in Alzheimer's disease. Front Biosci (Elite Ed) 4:2101-2109. Medline

Hsieh J, Eisch AJ (2010) Epigenetics, hippocampal neurogenesis, and neuropsychiatric disorders: unraveling the genome to understand the mind. Neurobiol Dis 39:73-84. CrossRef Medline

Jawerka M, Colak D, Dimou L, Spiller C, Lagger S, Montgomery RL, Olson EN, Wurst W, Göttlicher M, Götz M (2010) The specific role of histone deacetylase 2 in adult neurogenesis. Neuron Glia Biol 6:93-107. CrossRef Medline

Jones PL, Veenstra GJ, Wade PA, Vermaak D, Kass SU, Landsberger N, Strouboulis J, Wolffe AP (1998) Methylated DNA and MeCP2 recruit histone deacetylase to repress transcription. Nat Genet 19:187-191. CrossRef Medline

Kazantsev AG, Thompson LM (2008) Therapeutic application of histone deacetylase inhibitors for central nervous system disorders. Nat Rev Drug Discov 7:854-868. CrossRef Medline

Kempermann G (2012) New neurons for 'survival of the fittest'. Nat Rev Neurosci 13:727-736. CrossRef Medline

Kempermann G, Jessberger S, Steiner B, Kronenberg G (2004) Milestones of neuronal development in the adult hippocampus. Trends in neurosciences 27:447-452. CrossRef Medline 
Khan N, Jeffers M, Kumar S, Hackett C, Boldog F, Khramtsov N, Qian X, Mills E, Berghs SC, Carey N, Finn PW, Collins LS, Tumber A, Ritchie JW, Jensen PB, Lichenstein HS, Sehested M (2008) Determination of the class and isoform selectivity of small-molecule histone deacetylase inhibitors. Biochem J 409:581-589. CrossRef Medline

Kilgore M, Miller CA, Fass DM, Hennig KM, Haggarty SJ, Sweatt JD, Rumbaugh G (2010) Inhibitors of class 1 histone deacetylases reverse contextual memory deficits in a mouse model of Alzheimer's disease. Neuropsychopharmacology 35:870-880. CrossRef Medline

Korzus E, Rosenfeld MG, Mayford M (2004) CBP histone acetyltransferase activity is a critical component of memory consolidation. Neuron 42:961972. CrossRef Medline

Koshibu K, Gräff J, Beullens M, Heitz FD, Berchtold D, Russig H, Farinelli M, Bollen M, Mansuy IM (2009) Protein phosphatase 1 regulates the histone code for long-term memory. J Neurosci 29:13079-13089. CrossRef Medline

Kundu TK, Wang Z, Roeder RG (1999) Human TFIIIC relieves chromatinmediated repression of RNA polymerase III transcription and contains an intrinsic histone acetyltransferase activity. Mol Cell Biol 19:1605-1615. Medline

Lesburguères E, Gobbo OL, Alaux-Cantin S, Hambucken A, Trifilieff P, Bontempi B (2011) Early tagging of cortical networks is required for the formation of enduring associative memory. Science 331:924-928. CrossRef Medline

Lie DC, Song H, Colamarino SA, Ming GL, Gage FH (2004) Neurogenesis in the adult brain: new strategies for central nervous system diseases. Annu Rev Pharmacol Toxicol 44:399-421. CrossRef Medline

Lopez de Armentia M, Jancic D, Olivares R, Alarcón JM, Kandel ER, Barco A (2007) cAMP response element-binding protein-mediated gene expression increases the intrinsic excitability of CA1 pyramidal neurons. J Neurosci 27:13909-13918. CrossRef Medline

Lopez-Atalaya JP, Ciccarelli A, Viosca J, Valor LM, Jimenez-Minchan M, Canals S, Giustetto M, Barco A (2011) CBP is required for environmental enrichment-induced neurogenesis and cognitive enhancement. EMBO J 30:4287-4298. CrossRef Medline

Lubin FD, Roth TL, Sweatt JD (2008) Epigenetic regulation of BDNF gene transcription in the consolidation of fear memory. J Neurosci 28:10576-10586. CrossRef Medline

McQuown SC, Wood MA (2011) HDAC3 and the molecular brake pad hypothesis. Neurobiol Learn Mem 96:27-34. CrossRef Medline

Nan X, Ng HH, Johnson CA, Laherty CD, Turner BM, Eisenman RN, Bird A (1998) Transcriptional repression by the methyl-CpG-binding protein MeCP2 involves a histone deacetylase complex. Nature 393:386-389. CrossRef Medline

Oike Y, Hata A, Mamiya T, Kaname T, Noda Y, Suzuki M, Yasue H, Nabeshima T, Araki K, Yamamura K (1999) Truncated CBP protein leads to classical Rubinstein-Taybi syndrome phenotypes in mice: implications for a dominant-negative mechanism. Hum Mol Genet 8:387-396. CrossRef Medline

Oliveira AM, Wood MA, McDonough CB, Abel T (2007) Transgenic mice expressing an inhibitory truncated form of p300 exhibit long-term memory deficits. Learn Mem 14:564-572. CrossRef Medline

Oliveira AM, Estévez MA, Hawk JD, Grimes S, Brindle PK, Abel T (2011) Subregion-specific p300 conditional knock-out mice exhibit long-term memory impairments. Learn Mem 18:161-169. CrossRef Medline

Panteleeva I, Boutillier S, See V, Spiller DG, Rouaux C, Almouzni G, Bailly D, Maison C, Lai HC, Loeffler JP, Boutillier AL (2007) HPlalpha guides neuronal fate by timing E2F-targeted genes silencing during terminal differentiation. The EMBO J 26:3616-3628. CrossRef Medline

Peixoto L, Abel T (2013) The role of histone acetylation in memory formation and cognitive impairments. Neuropsychopharmacology 38:62-76. CrossRef Medline

Quinn CC, Gray GE, Hockfield S (1999) A family of proteins implicated in axon guidance and outgrowth. J Neurobiol 41:158-164. CrossRef Medline

Ricobaraza A, Cuadrado-Tejedor M, Pérez-Mediavilla A, Frechilla D, Del Rio J, García-Osta A (2009) Phenylbutyrate ameliorates cognitive deficit and reduces tau pathology in an Alzheimer's disease mouse model. Neuropsychopharmacology 34:1721-1732. CrossRef Medline

Ricobaraza A, Cuadrado-Tejedor M, García-Osta A (2011) Long-term phe- nylbutyrate administration prevents memory deficits in Tg2576 mice by decreasing Abeta. Front Biosci (Elite Ed) 3:1375-1384. Medline

Ricobaraza A, Cuadrado-Tejedor M, Marco S, Pérez-Otaño I, García-Osta A (2012) Phenylbutyrate rescues dendritic spine loss associated with memory deficits in a mouse model of Alzheimer disease. Hippocampus 22: 1040-1050. CrossRef Medline

Sahay A, Wilson DA, Hen R (2011) Pattern separation: a common function for new neurons in hippocampus and olfactory bulb. Neuron 70:582-588. CrossRef Medline

Schwab MH, Bartholomae A, Heimrich B, Feldmeyer D, Druffel-Augustin S, Goebbels S, Naya FJ, Zhao S, Frotscher M, Tsai MJ, Nave KA (2000) Neuronal basic helix-loop-helix proteins (NEX and BETA2/Neuro D) regulate terminal granule cell differentiation in the hippocampus. J Neurosci 20:3714-3724. Medline

Sekeres MJ, Neve RL, Frankland PW, Josselyn SA (2010) Dorsal hippocampal CREB is both necessary and sufficient for spatial memory. Learn Mem 17:280-283. CrossRef Medline

Selvi BR, Jagadeesan D, Suma BS, Nagashankar G, Arif M, Balasubramanyam K, Eswaramoorthy M, Kundu TK (2008) Intrinsically fluorescent carbon nanospheres as a nuclear targeting vector: delivery of membraneimpermeable molecule to modulate gene expression in vivo. Nano Lett 8:3182-3188. CrossRef Medline

Selvi BR, Cassel JC, Kundu TK, Boutillier AL (2010) Tuning acetylation levels with HAT activators: therapeutic strategy in neurodegenerative diseases. Biochim Biophys Acta 1799:840-853. CrossRef Medline

Selvi RB, Chatterjee S, Jagadeesan D, Chaturbedy P, Suma BS, Eswaramoorthy M, Kundu TK (2012) ATP driven clathrin dependent entry of carbon nanospheres prefer cells with glucose receptors. J Nanobiotechnology 10:35. CrossRef Medline

Sun Y, Nadal-Vicens M, Misono S, Lin MZ, Zubiaga A, Hua X, Fan G, Greenberg ME (2001) Neurogenin promotes neurogenesis and inhibits glial differentiation by independent mechanisms. Cell 104:365-376. CrossRef Medline

Tian F, Hu XZ, Wu X, Jiang H, Pan H, Marini AM, Lipsky RH (2009) Dynamic chromatin remodeling events in hippocampal neurons are associated with NMDA receptor-mediated activation of Bdnf gene promoter 1. J Neurochem 109:1375-1388. CrossRef Medline

Trouche S, Bontempi B, Roullet P, Rampon C (2009) Recruitment of adultgenerated neurons into functional hippocampal networks contributes to updating and strengthening of spatial memory. Proc Natl Acad Sci U S A 106:5919-5924. CrossRef Medline

Valor LM, Pulopulos MM, Jimenez-Minchan M, Olivares R, Lutz B, Barco A (2011) Ablation of CBP in forebrain principal neurons causes modest memory and transcriptional defects and a dramatic reduction of histone acetylation but does not affect cell viability. J Neurosci 31:1652-1663. CrossRef Medline

Valor LM, Viosca J, Lopez-Atalaya JP, Barco A (2013) Lysine acetyltransferases CBP and p300 as therapeutic targets in cognitive and neurodegenerative disorders. Current pharmaceutical design.

Verret L, Trouche S, Zerwas M, Rampon C (2007) Hippocampal neurogenesis during normal and pathological aging. Psychoneuroendocrinology 32:S26-S30. CrossRef Medline

Wang J, Chen J (2010) SIRT1 regulates autoacetylation and histone acetyltransferase activity of TIP60. J Biol Chem 285:11458-11464. CrossRef Medline

Winocur G, Moscovitch M, Bontempi B (2010) Memory formation and long-term retention in humans and animals: convergence towards a transformation account of hippocampal-neocortical interactions. Neuropsychologia 48:2339-2356. CrossRef Medline

Yang XJ (2004) Lysine acetylation and the bromodomain: a new partnership for signaling. Bioessays 26:1076-1087. CrossRef Medline

Yang XJ, Seto E (2007) HATs and HDACs: from structure, function and regulation to novel strategies for therapy and prevention. Oncogene 26 : 5310-5318. CrossRef Medline

Zajac MS, Pang TY, Wong N, Weinrich B, Leang LS, Craig JM, Saffery R, Hannan AJ (2010) Wheel running and environmental enrichment differentially modify exon-specific BDNF expression in the hippocampus of wild-type and premotor symptomatic male and female Huntington's disease mice. Hippocampus 20:621-636. CrossRef Medline 